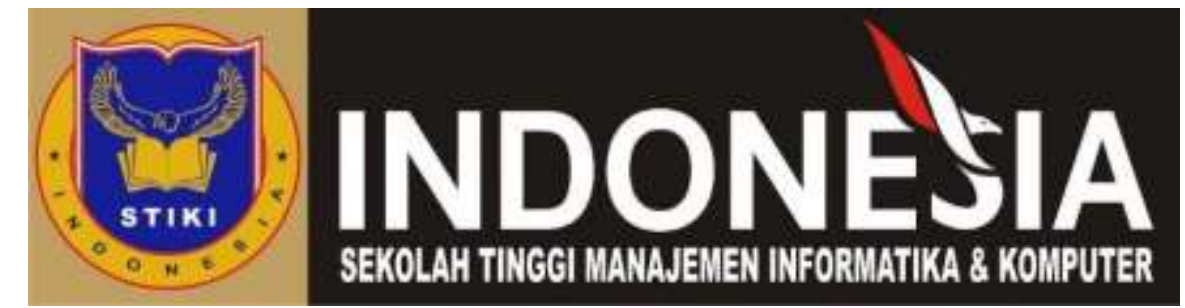

RANCANG BANGUN PAPAN KETIK ANDROID AKSARA BALI DENGAN PERBAIKAN PASANG AKSARA OTOMATIS

Tahun ke 1 dari rencana 1 tahun

IDA BAGUS ARY INDRA ISWARA, S.KOM, M.KOM (0824048801) PUTU PRABA SANTIKA, S.KOM, M.KOM, (0815128901)

I NYOMAN SAPUTRA WAHYU WIJAYA, S.KOM, M.CS (0826108901)

SEKOLAH TINGGI MANAJEMEN INFORMATIKA DAN KOMPUTER STIKOM INDONESIA

OKTOBER 2017 
Judul

\section{Peneliti Pelaksana}

Nama Lengkap

Perguruan Tinggi

NIDN

Jabatan Fungsional

Program Studi

Nomor HP

Alamat surel (e-mail)

Anggota (1)

Nama Lengkap

NIDN

Perguruan Tinggi

Anggota (2)

Nama Lengkap

NIDN

Perguruan Tinggi

Institusi Mitra (jika ada)

Nama Institusi Mitra

Alamat

Penanggung Jawab

Tahun Pelaksanaan

Biaya Tahun Berjalan

Biaya Keseluruhan
Rancang Bangun Virtual Keyboard Android Aksara Bali dengan Perbaikan Pasang Aksara Otomatis

IDA BAGUS ARY INDRA ISWARA, S.Kom, M.Kom

STMIK STIKOM Indonesia 0824048801

: Asisten Ahh

Teknik Informatika

081805468408

: aryindraiswara(agmail com

: PUTU PRABA SANTIKA S.Kom. M.Kom

: 0815128901

: STMIK STIKOM Indonesia

I NYOMAN SAPUTRA WAHYU WIJAYA S.KOM, M.Cs

: 0826108901

: STMIK STIKOM Indonesia

$\therefore$

$:-$

$:-$

: Tahun ke I dari rencana I tahun

: Rp 20,000,000

: Rp 20,000,000

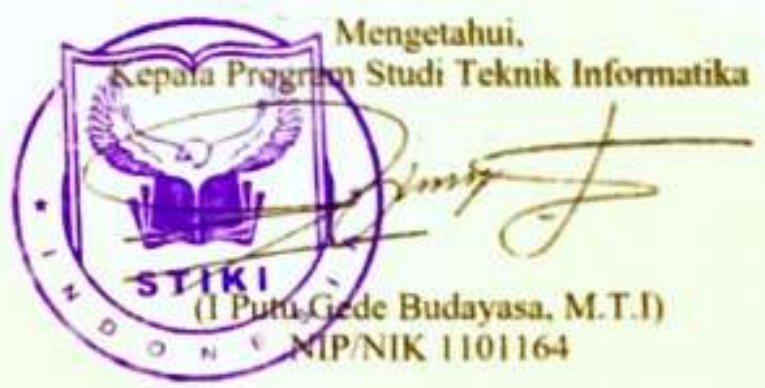

Kota Denpasar, 31 - 10 - 2017

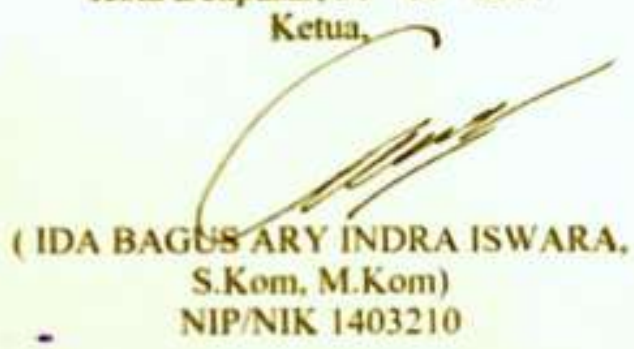

SQH PENCP Menyetujui.

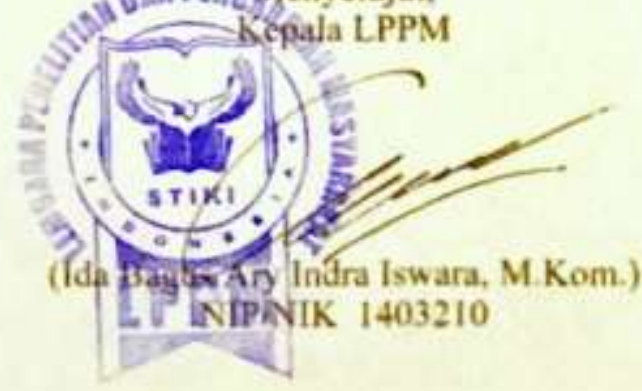




\section{RINGKASAN}

Bahasa Bali merupakan bahasa daerah yang dimiliki oleh masyarakat Bali. Wilian (2005) dalam bukunya kepunahan budaya, menyatakan bahasa Bali adalah salah satu bahasa yang sedang mengalami pergeseran penggunaan. Pergeseran penggunaan bukan hanya terjadi pada bahasa Bali, namun juga dalam aksara Bali, aksara Bali merupakan salah satu aksara tradisional Nusantara yang berkembang di Bali.

Kini aksara Bali sudah masuk dalam standar Unicode. Masuknya aksara Bali dalam Unicode sangat memudahkan untuk menampilkan aksara Bali dalam berbagai media. Aksara bali memiliki keunikan dalam banyaknya huruf yang digunakan. Pada tahun 2014 Cokorda Rai Adi Pramartha mengembangkan perangkat masukkan berupa papan ketik atau keyboard dan aplikasi bernama Tamiang untuk memudahkan pengguna dalam mengetik dan menggunakan aksara Bali pada perangkat komputer. Tata letak tombol pada Tamiang disusun sesuai dengan tingkat penggunaan masing-masing karakter. Saat ini Tamiang baru dikembangkan pada perangkat Komputer dengan konsep multiplatform.

Seiring dengan perkembangan teknologi, perangkat komputer perlahan mulai ditinggalkan, berdasarkan statistic dari statcounter.com dari tahun april 2015 sampai april 2016, pengguna sistem operasi untuk perangkat komputer semakin jauh tertinggal. Pengguna sistem operasi windows untuk Indonesia sebanyak $16.17 \%$, sedangkan pengguna sistem operasi mobile menempati posisi pertama di Indonesia yaitu sekitar 50.68\%. Sistem operasi tersebut adalah sistem operasi android.

Melihat dari banyaknya pengguna sistem operasi android yang ada di Indonesia, penulis ingin memberikan kontribusi untuk ikut melestarikan Aksara Bali dengan merancang dan membangun sebuah papan ketik aksara Bali android dengan perbaikan pasang aksara otomatis. Hasil dari penelitian ini adalah berupa Keyboard Virtual dengan nama PATIK Bali, Keyboard ini mampu melakukan auto correct pasang aksara wianjana. Hal ini terbukti dari hasil pengujian yang dilakukan menggunakan metode blackbox.

Kata Kunci :aksara Bali, android, keyboard, auto correction 


\section{PRAKATA}

Puji syukur kami panjatkan kehadapan Tuhan Yang Maha Esa, karena atas berkat dan rahmat-Nya, laporan penelitian yang berjudul RANCANG BANGUN PAPAN KETIK ANDROID AKSARA BALI DENGAN PERBAIKAN PASANG AKSARA OTOMATIS ini, selesai tepat waktu.

Akhir kata kami berharap agar laporan ini dapat bermanfaat untuk masyarakat dan khususnya warga Bali. Demikian laporan akhir ini kami buat, apabila terdapat kesalahan penulisan, kami mohon maaf dan kami ucapkan terima kasih.

Denpasar, 28 Oktober 2017

Penulis 


\section{DAFTAR ISI}

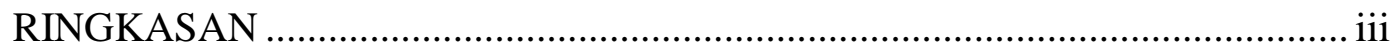

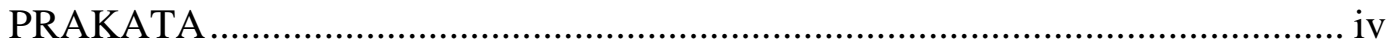

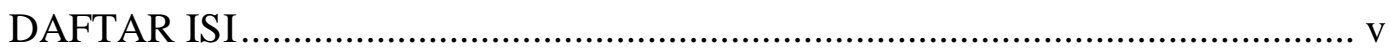

DAFTAR GAMBAR …............................................................................... vii

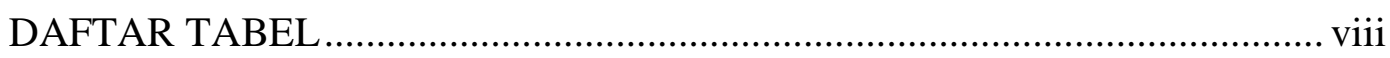

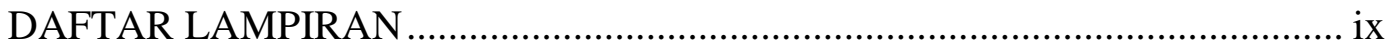

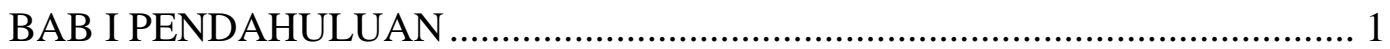

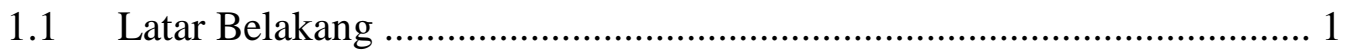

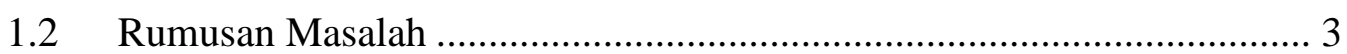

1.3 Batasan Masalah .................................................................................. 3

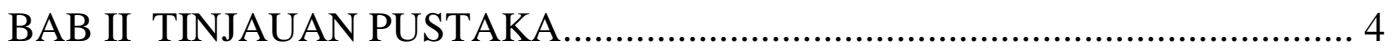

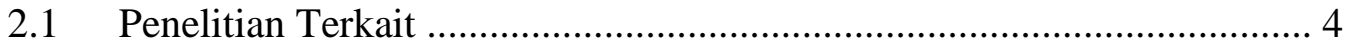

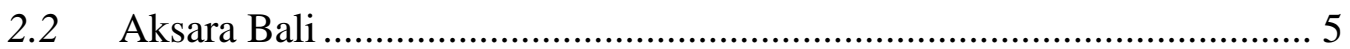

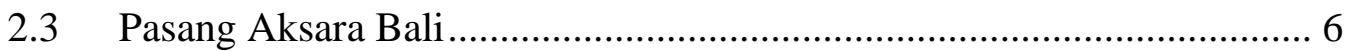

BAB III TUJUAN DAN MANFAAT PENELITIAN …................................... 32

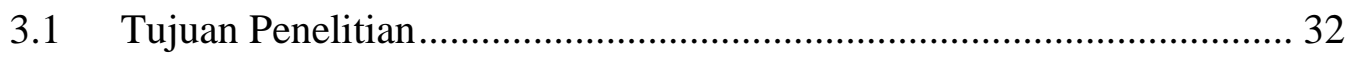

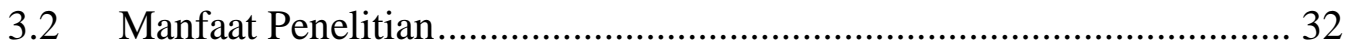

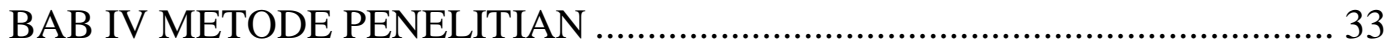

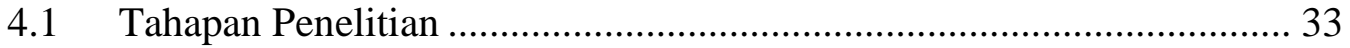

4.2 Rancangan Penelitian ........................................................................ 35

4.3 Teknik Pengumpulan dan Analisis Data ............................................. 36

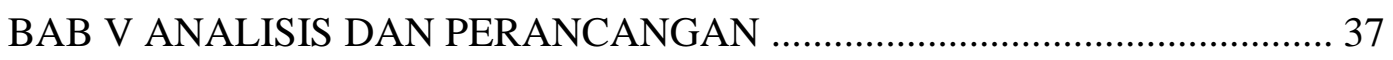

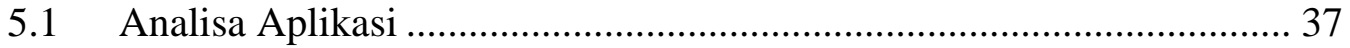

5.2 Perancangan Keyboard Virtual "PaTik Bali”....................................... 38

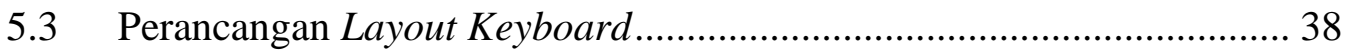

5.4 Pendekatan Algoritma Pasang Aksara Wianjana ................................. 42

BAB VI HASIL DAN PEMBAHASAN ...................................................... 46

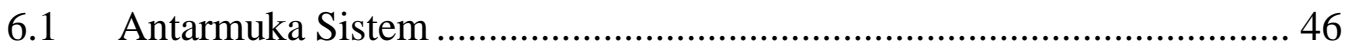

6.2 Implementasi keyboard PaTik Bali dengan Bahasa JAVA................... 48 
6.3 Pasang Aksara Wianjana pada PaTik Bali .......................................... 49

6.4 Method Perubahan Karakter................................................................. 52

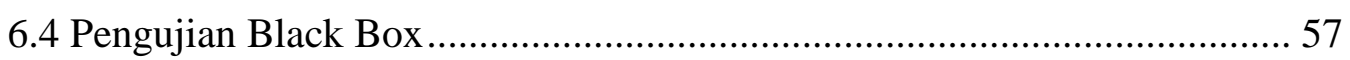

BAB VII KESIMPULAN DAN SARAN ...................................................... 59

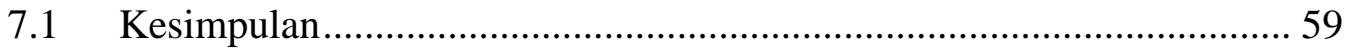

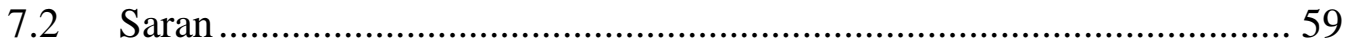

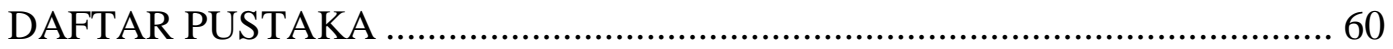

Lampiran 1. Susunan Organisasi Tim Peneliti dan Pembagian Tugas ................ 61

Lampiran 2. Biodata Ketua dan Anggota...................................................... 62

LAMPIRAN 3. SURAT PERNYATAAN KETUA PENELITI........................... 71 


\section{DAFTAR GAMBAR}

Gambar 1.1 Statistik Pengguna Android Tahun 2016 ......................................... 3

Gambar 2.1 Pasang Aksara Wianjana Warga Talawia ...................................... 31

Gambar 2.2Pasang Aksara Wianjana Warga Murdania..................................... 31

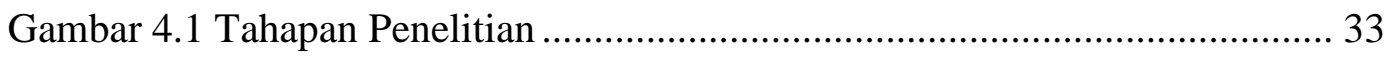

Gambar 4.2 Rancangan Penelitian ............................................................. 35

Gambar 5.1 Konsep Layer Keyboard Tamiang ................................................. 38

Gambar 5.2 Keyboard Tamiang Bali .............................................................. 39

Gambar 5.3 Keyboard PaTik Bali ................................................................ 40

Gambar 5.4 Hasil menahan Tombol pada Keyboard PaTik Bali ......................... 41

Gambar 5.5 Kode ASCII Aksara Bali ............................................................... 42

Gambar 5.6 Flowchart Algoritma Autocorrect .................................................... 43

Gambar 6.1 Antar Muka PaTik Bali .................................................................... 46

Gambar 6.2 Antarmuka Pop Up pada PaTik Bali ............................................ 47

Gambar 6.3Tombol Pengganti Keyboard ..................................................... 48

Gambar 6.4 Source Code class Main Activity .................................................. 49

Gambar 6.5Kode Method Perbandingan Dua Karakter ..................................... 50

Gambar 6.6 Kode Method Penggantian Karakter ............................................. 51

Gambar 6.7Method Perubahan Single Karakter .................................................. 54

Gambar 6.8 Method Perubahan dua karakter....................................................... 56 


\section{DAFTAR TABEL}

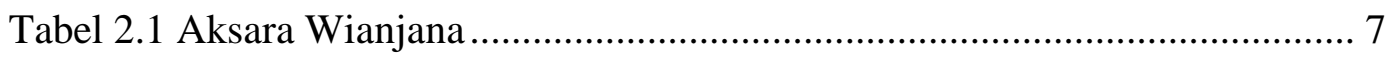

Tabel 6.1Aturan Pasang Aksara Rangkep Wianjana ........................................ 52

Tabel 6.2Pengujian Black Box PaTik Bali ..................................................... 57 


\section{DAFTAR LAMPIRAN}

Lampiran 1. Susunan Organisasi Tim Peneliti dan Pembagian Tugas

Lampiran 2. Biodata Ketua dan Anggota

Lampiran 3. Surat Pernyataan Ketua Peneliti 


\section{BAB I \\ PENDAHULUAN}

\subsection{Latar Belakang}

Manusia memerlukan Bahasa untuk mempermudah komunikasi satu sama lain. Beragam bahasa di dunia, mulai dari bahasa yang hanya digunakan di suatu daerah tertentu, hingga bahasa yang disepakati untuk menjadi bahasa internasional memiliki karakteristik yang berbeda-beda. Perkembangan teknologi berkontribusi memudahkan komunikasi yang terbatas akibat jarak dan perbedaan bahasa masingmasing daerah maupun negara. Selain itu komunikasi tidak hanya dilakukan seseorang dalam satu kota, tapi juga dimungkinkan untuk melakukan komunikasi antar masyarakat di pulau yang berbeda, atau bahkan antar masyarakat belahan dunia yang berbeda. Hal tersebut yang mendorong penentuan suatu bahasa untuk ditetapkan sebagai bahasa nasional atau bahasa internasional. Dampak negatif yang diakibatkan oleh penetapan suatu bahasa nasional atau internasional adalah pergeserean bahasa. Bahasa daerah akan tergeser dan digantikan dengan bahasa nasional dan bahasa internasional.

Bahasa Bali merupakan bahasa daerah yang dimiliki oleh masyarakat Bali. Wilian (2005) dalam bukunya kepunahan budaya, menyatakan bahasa Bali adalah salah satu bahasa yang sedang mengalami pergeseran penggunaan. Hal ini dapat disebabkan karena sikap masyarakat penuturnya yang tidak loyal terhadap bahasa daerahnya. Pergeseran bahasa (language shift) adalah perubahan secara tetap dalam pilihan bahasa seseorang untuk keperluan sehari-hari terutama sebagai akibat migrasi, atau terjadinya perubahan bahasa (language change), yakni perubahan dalam bahasa sepanjang suatu periode (Kridalaksana 1993: 169, 172). Pergeseran penggunaan bukan hanya terjadi pada bahasa Bali, namun juga dalam aksara Bali, aksara Bali merupakan salah satu aksara tradisional Nusantara yang berkembang di Bali.

Bahasa Bali digunakan sebagai bahasa alami yang digunakan dalam kehidupan sehari-hari, mengingat pentingnya pelestarian Bahasa Bali, pemerintah Provinsi Bali sudah berusaha melestarikan bahasa Bali dengan cara, salah satunya 
adalah dengan menerbitkan Peraturan Gubernur Bali Nomor 20 Tahun 2013 tentang bahasa, aksara dan sastra daerah Bali pada pendidikan dasar dan menengah. Pada Peraturan Gubernur Bali Nomor 20 Tahun 2013 disebutkan bahasa, aksara dan Sastra Bali diajarkan pada semua jenjang pendidikan dasar dan menengah sebagai mata pelajaran di Provinsi. Bupati/Walikota dapat mewajibkan satuan pendidikan untuk mengajarkan bahasa, aksara dan sastra Bali minimal 2 jam pelajaran per minggu.

Tidak hanya pemerintah yang berusaha melestarikan bahasa dan aksara Bali, beberapa masyarakat juga berusaha untuk melestarikannya. Salah satunya adalah I Made Suatjana mengajukan proposal agar aksara Bali dimasukkan dalam Unicode atau ISO 10646. Kini aksara Bali sudah masuk dalam standar Unicode. Masuknya aksara Bali dalam Unicode sangat memudahkan untuk menampilkan aksara Bali dalam berbagai media. Aksara bali memiliki keunikan dalam banyaknya huruf yang digunakan. Pramartha dan Dwidasmara (2014) mengembangkan perangkat masukkan berupa papan ketik atau keyboard dan aplikasi bernama Tamiang untuk memudahkan pengguna dalam mengetik dan menggunakan aksara Bali pada perangkat komputer. Tata letak tombol pada Tamiang disusun sesuai dengan tingkat penggunaan masing-masing karakter. Saat ini Tamiang baru dikembangkan pada perangkat Komputer dengan konsep multiplatform.

Seiring dengan perkembangan teknologi, perangkat komputer perlahan mulai ditinggalkan, berdasarkan statistic dari statcounter.com dari tahun april 2015 sampai april 2016, pengguna sistem operasi untuk perangkat komputer semakin jauh tertinggal. Gambar 1.1 memperlihatkan pengguna sistem operasi windows untuk Indonesia sebanyak $16.17 \%$, sedangkan pengguna sistem operasi mobile menempati posisi pertama di Indonesia yaitu sekitar 50.68\%. Sistem operasi tersebut adalah sistem operasi android.

Berdasarkan uraian diatas, pada penelitian ini akan dibuat papan ketik yang dapat digunakan untuk perangkat android, mengingat sistem operasi android merupakan sistem operasi terbanyak yang digunakan di Indonesia yang terlihat pada Gambar 1.1. papan ketik ini dapat mengetikkan aksara Bali langsung pada perangkat Android. Selain sebagai sarana masukan, pada papan ketik ini akan 
diimplementasikan kemampuan untuk melakukan perbaikan secara otomatis terhadap kesalahan aturan penulisan (pasang aksara Bahasa Bali).

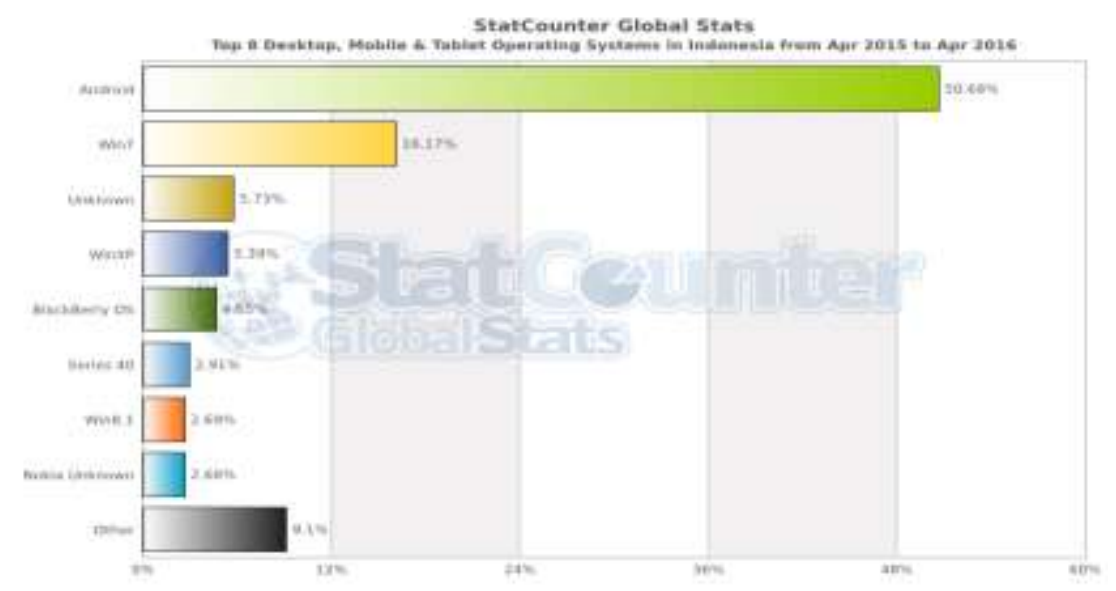

Gambar 1.1 Statistik Pengguna Android Tahun 2016

\subsection{Rumusan Masalah}

Berdasarkan latar belakang yang telah dipaparkan, permasalahan yang akan dibahas dalam penelitian ini adalah bagaimana merancang dan membangun keyboard android aksara Bali yang dapat melakukan perbaikan secara otomatis untuk kesalahan penerapan aturan pasang aksara Bahasa Bali.

\subsection{Batasan Masalah}

Batasan masalah dari penelitian ini adalah fitur autocorrect dilakukan dengan menggunakan pendekatan Pasang Aksara rangkep Wianjana khusus pada aksara talawia, murdania, dan osthia. 


\section{BAB II \\ TINJAUAN PUSTAKA}

Pustaka-pustaka yang melandasi timbulnya gagasan dan permasalahan yang diteliti pada penelitian ini terbagi menjadi dua lingkup, yakni penelitian yang terkait tentang penerapan aksara bali dalam teknologi, dan teori-teori yang terkait dengan aturan penulisan pasang aksara bali.

\subsection{Penelitian Terkait}

Media pembelajaran tentang aksara Bali telah dikemas dalam bentuk aplikasi yang dapat dipasang atau diinstall pada gadget yang menggunakan sistem operasi Android (Setiyawan, 2014). Penelitian yang dilakukan berfokus pada media pembelajaran untuk mengenal bentuk, bunyi, dan tulisan. Pilihan belajar akan terdapat beberapa menu pembelajaran diantaranya adalah belajar aksara Bali dasar, belajar angka Bali, dan merangkai kata. Aplikasi pembelajaran ini menggunakan permainan sebagai media untuk mengemas hal-hal tersebut. Penelitian tersebut belum membahas mengenai aturan-aturan penulisan seperti pasang aksara dan pasang pageh.

Penelitian yang dilakukan oleh Wirdiani (2015), membahas mengenai sebuah media pembelajaran tentang aksara Bali khususnya mengenai pasang pageh. Media pembelajaran tersebut dikemas ke dalam bentuk game edukasi. Game edukasi "Pasang Pageh Aksara Bali" diimplementasikan pada platform Android. Game ini dibuat menggunakan aplikasi Corona yang berbasis Bahasa Pemrograman Lua dan dengan menggunakan Metode Drag and Drop. Game edukasi ini menitikberatkan pada pembelajaran bagaimana memahami tentang Pasang Pageh Aksara Bali yang benar. Pasang Pageh merupakan tata tulis pada aksara Bali. Dengan tersedianya media pembelajaran ini diharapkan dapat membantu para akademisi untuk memahami bagaimana aturan-aturan dalam penulisan aksara Bali.

Salah satu fasilitas yang sering digunakan untuk melakukan pemrosesan word untuk tulisan yang menggunakan aksara Bali adalah Bali Simbar. Pada tahun 1996 Bali Simbar, program pengetikan Aksara Bali dengan komputer diperkenalkan kepada masyarakat. Hampir tidak ada perbaikan sejak saat tersebut. 
Pada tahun 2005 aksara Bali diusulkan agar masuk dalam daftar UNICODE atau ISO 10646. Dan pada pertengahan tahun 2006 aksara Bali telah terdaftar dalam UNICODE / ISO 10646. Langkah selanjutnya seharusnya untuk aksara Bali dibuatkan program IME (cara pengetikan) untuk Microsoft WINDOWS, sehingga aksara Bali bisa menjadi Smart Font (huruf pintar), sehingga dengan mudah bisa dipakai (Anonim, 2009). Bali simbar masih memiliki kekurangan, Bali Simbar hanya dapat digunakan pada aplikasi Microsoft word.

Tamiang Bali merupakan aplikasi word processor yang dikembangkan untuk membuat dan melakukan pengeditan file dalam bentuk aksara bali. Fungsi dasar dari sebuah aplikasi pemrosesan word seperti open, save, print dan create new files, export files menjadi PDF/JPG, copy, cut, paste dan sebagainya. Aplikasi teresebut dirancang agar dapat dijalankan pada berbagai sistem operasi, seperti Windows, LINUX, dan MAC (Paramartha, 2014).

Aplikasi word processing untuk aksara Bali yang tersedia belum memberikan fitur autocorret untuk aturan pasang aksara. Ketika ada kesalahan penulisan atau ada aturan yang dilanggar, diharapkan aplikasi dapat memberikan perbaikan secara otomatis. Penulis ingin mengembangkan aplikasi Tamiang Bali yang dapat berjalan pada sistem operasi android.

\subsection{Aksara Bali}

Pengertian aksara Bali menurut Bagus (1980 : 99) bahwa aksara bersinonim dengan sastra. Kata sastra mempunyai bentuk turunan nyastra berarti berilmu. Berdasarkan pendapat di atas dapat dijelaskan bahwa seseorang agar dapat disebut sebagai orang berilmu, maka orang tersebut harus banyak membaca. Seperti kita ketahui bahwa sumber dari ilmu itu adalah lontar-lontar. Lontar-lontar tersebut ditulis dengan menggunakan aksara Bali. Sedangkan isi lontar tersebut bermacammacam, ada yang menulis tentang astronomi, ilmu bangunan, silsilah keturunan (babad), pengobatan (usada) dan lain sebagainya. Untuk dapat membaca lontar tersebut orang harus mengetahui tentang aksara Bali. Untuk bisa menulis lontar maka harus menguasai ilmu tentang Aksara Bali yang disebut dengan Pasang Aksara dan Pasang Pageh. 


\subsection{Pasang Aksara Bali}

Pasang aksara Bali adalah teori atau tata cara menulis aksara Bali. Pasang aksara Bali digunakan untuk menuntun dalam menulis aksara Bali. Menurut Simpen (2004:1) aksara Bali dapat dikelompokkan menjadi tiga kelompok, yaitu aksara Wreastra, aksara Swalalita dan aksara Modre. Aksara wreastra adalah aksara Bali yang digunakan untuk menulis basa Bali lumrah seperti: urak (surat tugas belajar/ desa), pipil, pengumuman/ pemberitahuan dan lain-lainnya(Simpen, 2004:1). Adapaun aksara yang dimaksud :

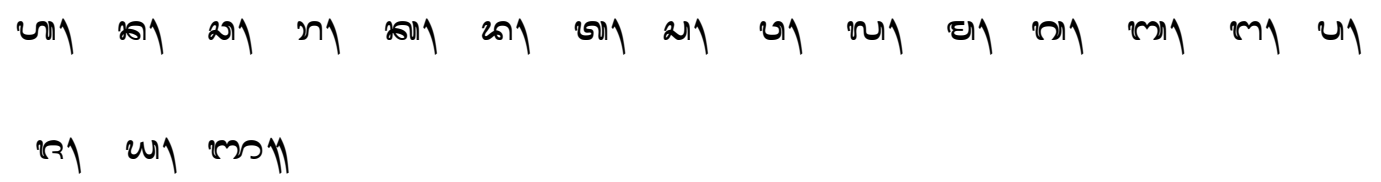

Gantungannya :

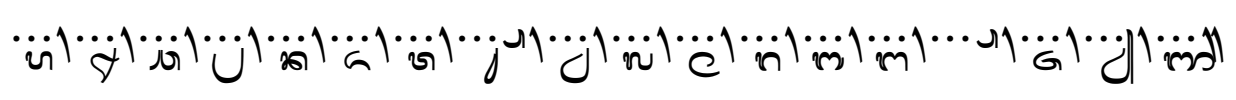

Huruf di atas dibaca:

ha, na, ca, ra, ka, da, ta, sa, wa, la, ma, ga, ba, nga, pa, ja, ya, nya.

Jadi seluruh aksara ini berjumlah 18 buah, sedangkan pangangge suaara wreastra terdiri dari :

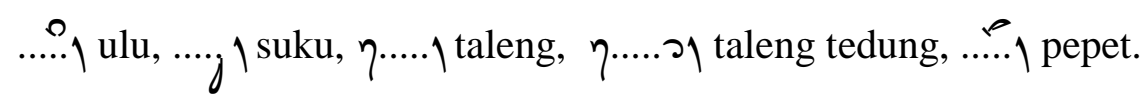

Aksara Swalalita adalah aksara yang digunakan untuk menulis kesusastraan Kawi, seperti menulis kekawin, panva-parwa dan sebagainya. Jumlah aksara swalalita secara keseluruhan adalah 47 buah yang terdiri atas 14 vokal (aksara suara) dan 33 buah konsonan (aksara wianjana) )(Simpen, 2004:1). Yang termasuk dalam aksara suara:
(a) उ०ग mु। mal

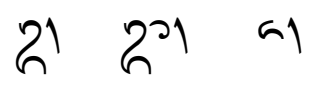
ฆั। হุ ฉूग
บุ।

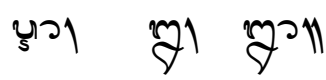


Aksara Bali yang termasuk dalam aksara wianjana dapat dilihat pada Tabel 2.1.

Tabel 2.1 Aksara Wianjana

\begin{tabular}{|c|c|c|c|c|c|c|c|c|c|}
\hline No & $\begin{array}{c}\text { Aksaral } \\
\text { Warga }\end{array}$ & $\begin{array}{c}\text { Alpa } \\
\text { Pran } \\
a\end{array}$ & $\begin{array}{c}\text { Maha } \\
\text { Pran } \\
a\end{array}$ & $\begin{array}{c}\text { Alpa } \\
\text { Pran } \\
\quad a\end{array}$ & $\begin{array}{c}\text { Maha } \\
\text { Pran } \\
\quad a\end{array}$ & $\begin{array}{c}\text { Anu } \\
\text { Suar } \\
a\end{array}$ & $\begin{array}{c}\text { Arda } \\
\text { swar } \\
\quad a\end{array}$ & Usma & Wisarga \\
\hline 1 & Kantia & 200 & $2 \Omega$ & 8 & $n \omega$ & $m$ & - & - & un \\
\hline 2 & Talawia & 29 & نقّ & $R$ & $\delta$ & ת m & $u$ & (จ) & - \\
\hline 3 & $\begin{array}{l}\text { Murdani } \\
a\end{array}$ & $\vartheta$ & $\varepsilon$ & 20 & 20 & מחו & n & $w$ & - \\
\hline 4 & Dantia & जU & W & 20 & $\omega$ & 200 & $n$ & as & - \\
\hline 5 & Astia & ת & $v$ & $m$ & 20 & घा & ט & - & - \\
\hline
\end{tabular}

Pasang aksara Bali adalah ejaan atau aturan dalam menulis Bali dengan menggunakan aksara Bali. Ejaan atau pasang aksara Bali yang digunakan dalam aksara Bali adalah sistem silabik. Ejaan ini menggambarkan suatu suku silabik dengan dua buah fonem yaitu fonem konsonan atau fonem vokal. Untuk menunjukan bunyi-bunyi vokal yang terkandung oleh gambar huruf konsonan yang ada, digunakan sandang suara (Medra, dkk 2002:12).

Contoh :

(na) akan menjadi $n i, n u, n e, n o$, ne setelah huruf tersebut diberi sandang suara : 


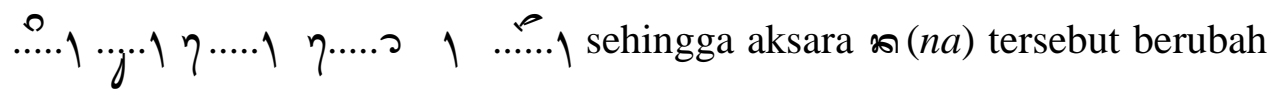

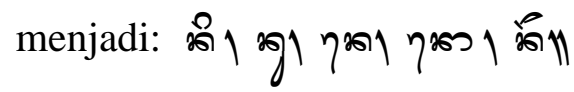

Bahasa bali (khususnya dalam aksara Bali) selain dikenal dengan nama sandang suara, dikenal pula adanya pengangge suara dan pengangge tengenan. Pengangge suara sering juga disebut pengangge aksara yang berasal dari aksara ardasuara. yang termasuk pengangge suara adalah (bunyi setengah konsonan) seperti: y,r,l,w dalam kaitannya dengan kluster.

contoh :

$$
\begin{aligned}
& \text { tabia = vory } \\
& \text { putra }=\text { yoyn } \quad \text { blalu }=\text { ingyn }
\end{aligned}
$$

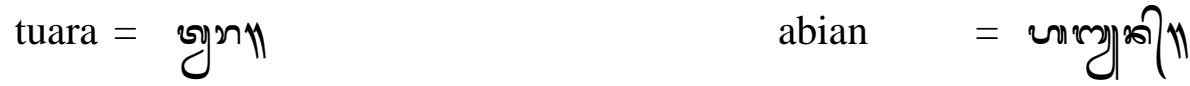

\section{Pasang Aksara Tengenan}

Tengenan dalam bahasa bali sering juga disebut dengan istilah nengen, yang dimaksud dengan negen dalam bahasa Bali adalah konsonan yang terletak pada akhir suku mati (Medra, dkk 2002:18). Pendapat lain mengatakan bahwa yang dimaksud dengan tengenan adalah konsonan atau wianjana yang terletak pada akhir dari sebuah kata yang belum mendapat vokal (sandang suara) (Simpen, 2004 : 12). Dalam penerapannya, yakni dalam menulis dengan aksara Bali dikenal istilah tengenan mejala. Yang dimaksud dengan tengenan mejalan adalah aksara-aksara yang sudah nengen atau mati (wianjana), kemudian kerena dibubuhi oleh aksara suara di belakangnya lalu hidup kembali menjadi satu suku dengan aksara yang mengikutinya (Medra, dkk. 2002:18).

contoh :
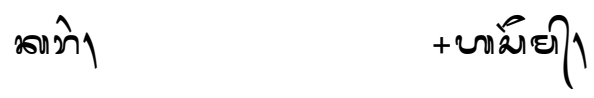

menjadi

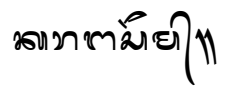




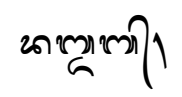

+งทnภภी।

menjadi

20

$\|$

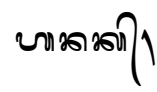

+ जथुओ menjadi

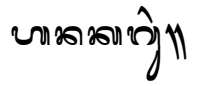

Menurut Medra. dkk (2002:18) Tengenan dalam penggunaanya memiliki pengangge yang disebut dengan istilah pengangge tengenan. Adapun yang termasuk dalam pangangge tengenan adalah cecek ....., bisah ..... $\{$, surang ......, adegadeg .....? n. Selanjutnya di bawah ini akan diuraikan aturan atau uger-uger pasang aksara pangangge tengenan tersebut.

\section{Penggunaan Cecek}

Cecek dilambangkan dengan .... adalah berfungsi sebagi pengganti wianjana mी 1 . Adapun uger-uger atau aturannya adalah sebagai berikut:

a. Cecek ( ..... ) dipakai pada suku kata terakhir :

contoh :

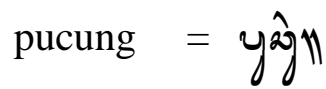

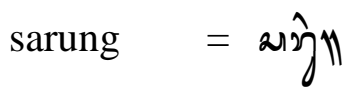

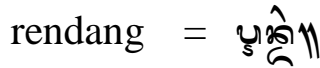

barang $=$ minก๊

b. Cecek ( ..... ) dipakai pada kata-kata yang kedua suku katanya sama walaupun sudah mengalami proses nasalisasi (kapolahang) . contoh :
bengbeng $=\eta$ ख्रें ल्योग

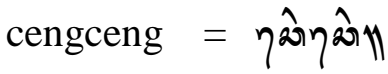




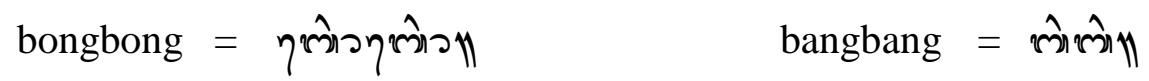

c. Cecek (.....) pada suku kata pertama yang ada pada kata dasar yang konsonannya berbeda diganti dengan tengenan $\mathrm{m}$.

contoh :

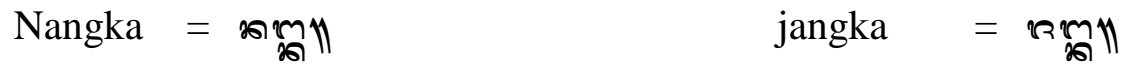

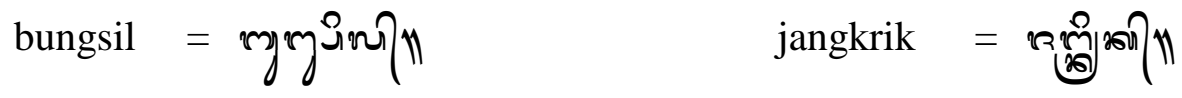

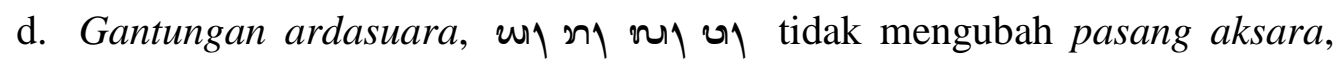
kecuali la (几s) tidak boleh bersusun tiga.

contoh :

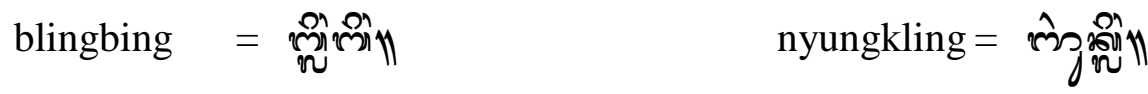

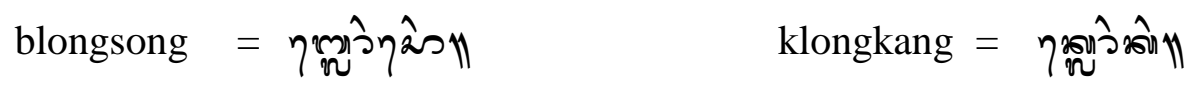

\section{Penggunaan Bisah}

Bisah dilambangkan dengan ....... $\{$ bisah berfungsi sebagai pengganti

Wianjana $\mathbf{v 1}$. Adapun uger-uger atau aturannya hampir sama dengan

Cecek, yaitu :

a. Bisah (...... $)$ dipakai pada suku kata terakhir. 
contoh :

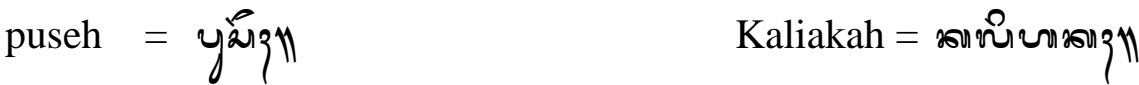

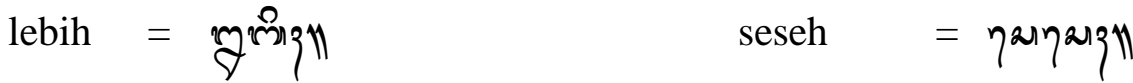

b. Bisah (...... $)$ dipakai pada kata-kata yang kedua suku katanya sama, walaupun suku kata yang pertama sudah mengalami proses nasalisasi (kapolahang).

contoh :

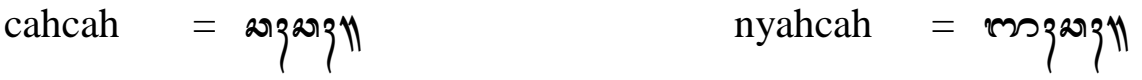

$$
\begin{aligned}
& \text { kohkoh }=\eta \operatorname{sos}\{\eta \operatorname{sos}\{\mu \quad \text { Ngohkoh }=\eta \operatorname{mo} \eta \eta \operatorname{sos}\{\mu
\end{aligned}
$$

c. Bisah (..... q) pada suku kata pertama yang ada pada kata dasar yang konsonannya berbeda diganti dengan tengenan $2 \pi$.

Contoh :

$$
\begin{aligned}
& \text { Cihna = 2ิq2aा menjadi 2ิyㅔ }
\end{aligned}
$$

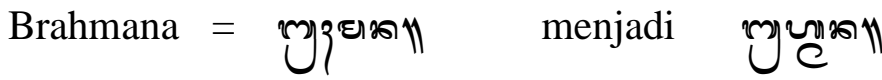

\section{Pengunaan Surang}

Surang dilambangkan dengan (......) adalah berfungsi sebagai pengganti wianjana थी yang masih kita dapatkan dalam lontar-lontar secara utuh. 
Penggunaan tengenan $\Re$ di sekolah-sekolah, semuanya diganti dengan surang (.....) saja.

contoh :

lawar = nuv̀n

purna = ỳmin

warna = v̀min

damar = 2काोग

borbor

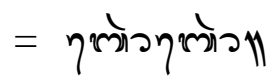

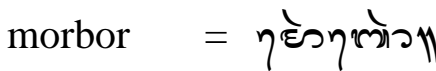

4. Penggunaan Adeg-adeg

Adeg-adeg dilambangkan dengan (....? ) adeg-adeg berfungsi untuk mematikan aksara tersebut sehingga menjadi nengen atau mati (konsonan). Adeg-adeg hanya dipakai pada suku kata terakhir kecuali bila ada suku kata bersusun tiga, adeg-adeg bisa dipakai di tengah kata.

contoh :

taman

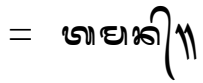

adan

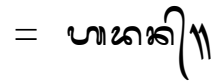

budal

$$
=\operatorname{mg} 200011
$$

malaib

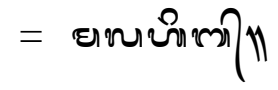

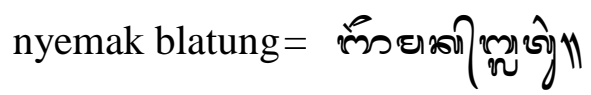

\section{Pasang aksara Ardasuara}

Aksara ardasuara artinya aksara setengah suara, yaitu aksara : ya, w1 ra, n† la, n\ wa, ज川. Aksara Ardasuara mempunyai fungsi dua buah, yaitu 
sebagai aksara suara dan aksara wianjana (Medra, dkk 2002:16). Di bawah ini akan di uraikan tentang pasang aksara ardasuara.

1. Aksara ardasuara bila ditulis yang berfungsi Wianjana harus ditulis sejajar seperti contoh di bawah ini ;

भुजै। tidak boleh ditulis थै।

gुopl tidak boleh ditulis gyl

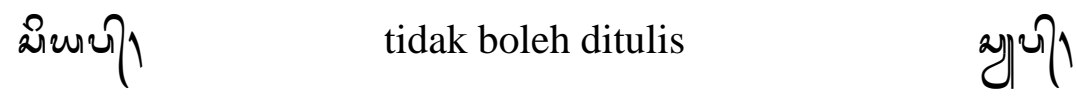

लिखy| tidak boleh ditulis ख्यु)

लेखो। tidak boleh ditulis क्ञो

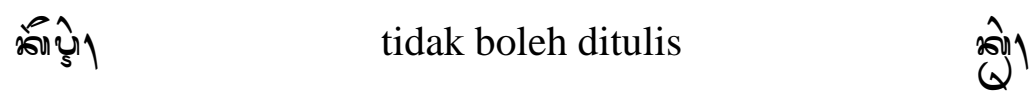

2. Aksara Ardasuara berfungsi sebagai aksara suara apabila menyatu dengan Wianjana di depannya.

contoh:

\begin{tabular}{|c|c|c|c|}
\hline खैघटॉ⿰। & $=$ sempyar & 296| & $=$ candra \\
\hline जोक्षे| & $=$ angklung & 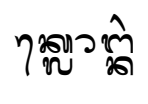 & = klongkang \\
\hline हิ) & $=$ griya & gyul & = bwaya \\
\hline
\end{tabular}

1. Kata dasar atau kruna lingga, apabila ucapan di depan $r, 1$ mendapat awalan ma,ka,sa,pa ditulis seperti contoh di bawah ini :

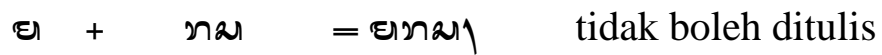

gु211

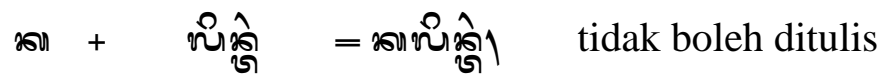

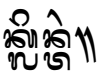




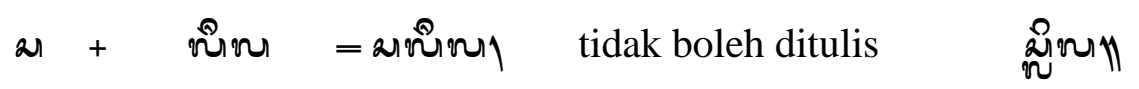

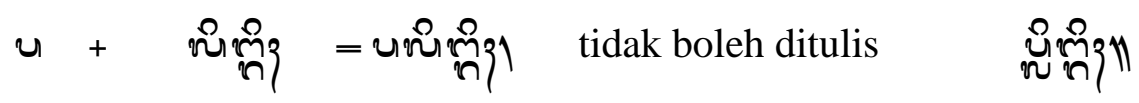

2. Aksara $\Omega$ (r) dan aksara n\ (1) tidak boleh ditulis memakai pepet (.......), aksara 2 (r) diganti dengan (l) diganti dengan $\quad \vartheta$ (lelenga), seperti contoh di bawah ini;
regu = usgu
reko $\quad=$ ü
rena $=$ บูinn
legu $\quad=q g y$
lekad $=\eta^{2001200 / \Lambda}$

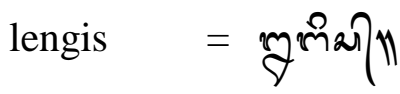

3. Apabila lelenga ( $\vartheta$ ) memakai gantungan maka lelenga $(\boldsymbol{\eta})$ kembali ke bentuk asalnya, yaitu ( $\sim$ ) tetapi apabila rerepa ( tidak berubah.

contoh:
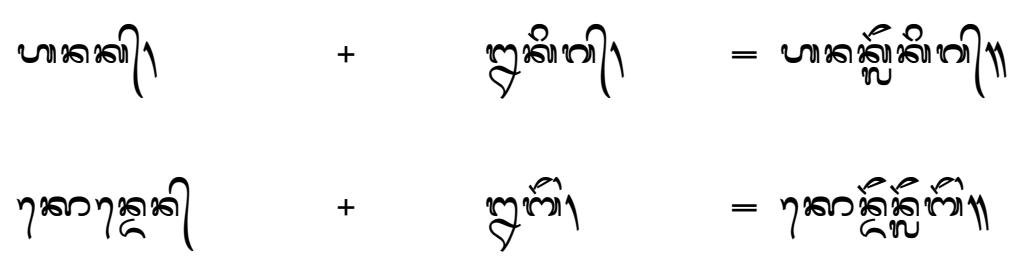

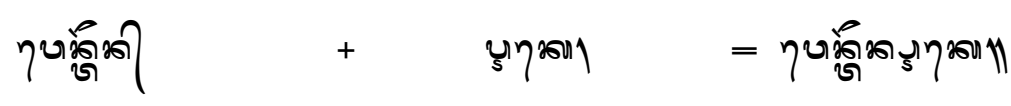

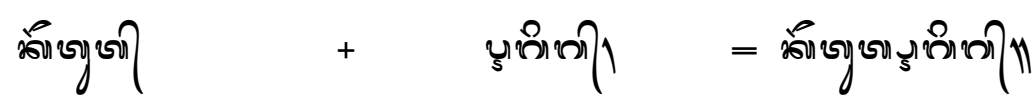


4. Setiap kata dasar atau kruna lingga apabila suku kata akhir berbunyi $u$ (....... ) ) atau berbunyi $i(. . . .$.$) dan bila mendapat akhiran an, ang, in, diganti dengan$ $w a($ (v)....j) dan $y a(u|\cdots j|)$.

contoh :

\begin{tabular}{|c|c|c|c|c|}
\hline घry & + & जभคी & $=$ घाभुजा? & $=$ घाभुभीय \\
\hline & + & जो। & $=$ uryजे। & = uñyl \\
\hline 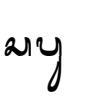 & + & ที่คी। & 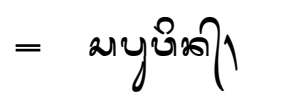 & = มบิซึ|॥ \\
\hline जाn & + & जो & ज仓ુ̂ि। & $=$ \\
\hline
\end{tabular}

\section{A. Pengangge Suara}

Pangangge suara digunakan untuk menandakan bunyi vokal yang menyertai aksara wianjana atau konsonan yang ada. Namun disamping fungsi itu pangangge suara seperti tedong, ulu sari, suku ilut, taleng marepa, taleng marepa matedong, pepet matedong, juga memiliki aturan-aturan tersendiri sesuai dengan kedudukan/posisi penulisannya.

- Tedong 0

Dalam penulisannya tedong ditulis secara melekat pada aksaranya.

Contoh:

$H, N, C, R, K, G, T, M, S, W, L, P, D, Y, \sim$,

Contohnya : $b+\cdots \cdot 0=2$ 
Tedong digunakan untuk menuliskan persandian $\mathrm{a}+\mathrm{a}=\overline{\mathrm{a}}$. Hal ini dapat dilakukan baik dalam sebuah kata, maupun dalam dua buah kata yang mendapatkan sandi.

Contoh :

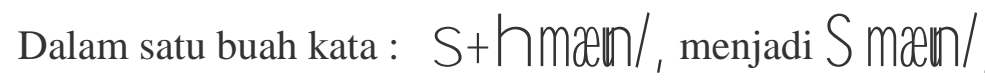

Dalam dua buah kata: $k r$ *⿻丷木h $s \mathrm{~m} /$, menjadi $\mathrm{r} /$ os $\mathrm{m} /$,

- Ulu sari Ü

Secara umum penggunaan ulu sari sebagai berikut. Sandi $i+i=\bar{I}$

Contohnya: $\quad d i t h b i$ menjadi $d i$

Sandi $\mathrm{a}+\mathrm{i}=\overline{\mathrm{I}}$

Contohnya: $\quad m+h k \mu$ menjadi $m \hat{k} \mu_{1}$

Untuk menuliskan nama wanita.

Contohnya : ed Wù (gelar dewa wanita)

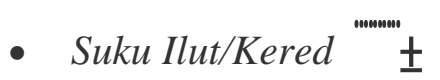

Secara umum penggunaan suku ilut ditemukan sabagai berikut. Suatu kata penulisannya diawali dengan u $(h)$, mendapat awalan pa- $(p)$, ma- $(m)$, ka-(k ), maka penulisannya u menjadi suku ilut. 
Contoh : $k+h m_{1,}^{\prime}$ menjadi $k$ 近,

Suatu kata yang suku pertamanya mendapat u dan menggunakan surang, maka penulisannya menjadi suku ilut.

Contoh : $s$ y 2 , menjadi $s \notin k /$,

- Taleng Marepa E

Taleng marepa juga disebut taleng sari, yang penggunaannya apabila suatu

kata diawali dengan vokal e (eh ), dan mendapat awalan ka- (K ), sa-(S ),

ma-(m).

Contoh $: k+e h r *$ menjadi Ek $r \mid n /$,

- Taleng Marepa Matedong E

Taleng marepa matedong maksudnya adalah suatu kata penulisan aksara Bali yang menggunakan atau mendapatkan tedong dalam satu aksara.

Contoh: EK r W, (kaurawa)

- Pepet Matedong "'"'"0

Pepet matedong maksudnya adalah suatu kata dalam penulisannya mendapat pengangge suara pepet dan tedong dalam satu aksara. Dan ini 
digunakan apabila suatu kata diawali dengan vokal e $(h)$, mendapat awalan

ka- $(k)$, pa- $(p)$.

Contoh $: p+h \|_{i}^{*}$ menjadi $P \mid j$

Contoh di dalam ejaan/pasang aksara Purwadresta menjadi tumpuk, seperti

$$
\text { P)j } * \text { menjadi } \rho \ddot{\theta} \text {, }
$$

\section{B. Pengangge Ardasuara}

Pangangge ardasuara maksudnya adalah pengangge yang berasal dari aksara

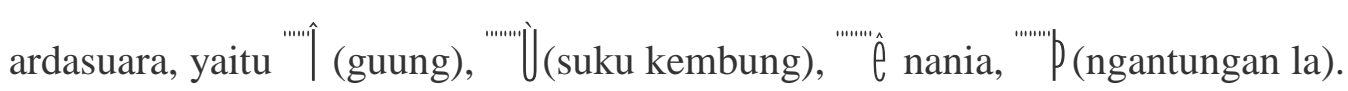

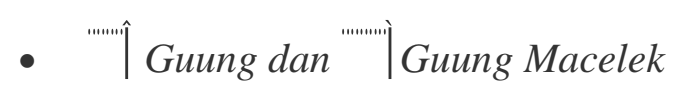

Guung dan guung macelek memilki fungsi untuk melambangkan ra dan ṛ. Contoh :

Cakra $=C k \hat{~}$

Sregep $=s \lg p /$,

- Suku Kembung "'-'Ù

Suku kembung memiliki fungsi untuk melambangkan penulisan gantungan ua dan wa. 
Contoh :

Kuasa $=k \dot{b}$,

- Nania ${ }^{n+\cdot n}$

Nania memiliki fungsi untuk melambangkan penulisan gantungan ya.

Contoh :

Sadia $=S d \hat{~}$

- Gantungan la

Gantungan la memiliki fungsi untuk melambangkan penulisan gantungan la pada kluster 1 .

Contoh :

$$
\mathrm{Blau}=b \text { \& } \mu
$$

\section{Pengangge Tengenan}

Pengangge tengenan maksudnya adalah pengangge yang berasal dari tengenan wianjana, yaitu cecek, bisah, surang, adeg-adeg.

- Cecek $^{\text {'"'* } *}$

Pengangge tengenan cecek berasal dari tengenan ng.

Pada suku kata terakhir. Contoh : $\mathrm{K} \mathrm{C}_{1}^{*}$

Pada kata-kata yang kedua sukunya sama, dan keduanya mendapat tengenan ng, walaupun mendapat nasal atau ardasuara.

Contoh : 
Cangcang $=C^{*} *$

Mangbang $=m$ 为 $*$

Pada kata-kata yang suku katanya berbeda warga, baik yang terdiri atas dua suku maupun tiga suku, dan suku kedua atau ke tiga dari akhir kata mendapat tengenan ng, maka tidak diganti dengan cecek.

Contoh:

Nangka $=n \mid \emptyset$

Tenggala $=t \| b^{\prime}$,

Untuk menghindari aksara susun tiga.

Contoh :

Angklung $=h$

- Bisah "',

Bisah berasal dari tengenan wisarga. Adapun pemakaiannya, sebagai berikut. Bisah dipakai pada tengenan wisarga terakhir.

Contoh :

Satuh $=S t \mu_{1}$

Alih $=h \mid i$,

Bisa dipakai pada kata-kata yang kedua sukunya sama dan keduanya mendapat tengenan wisarga, walaupun mendapat anusuara atau ardasuara. 
Contoh :

Cahcah $=C_{1}^{\prime} C_{1}^{\prime}$

Nyahcah $=2 ; C ;$,

Bisa diganti dengan wisarga bila suku katanya berbeda warga, baik yang terdiri atas dua suku maupun tiga suku, dan suku kedua atau suku ketiga dari akhir kata mendapat tengenan wisarga.

Contoh :

Cihna $=C h \hat{A}$

- Surang "'."'

Pangangge tengenan surang berasal dari tengenan r. Adapun pemakaiannya, sebagai berikut.

Pada kata-kata yang mendapat tengenan $r$.

Contoh :

Damar $=d m \mid$

Galar $=g||$

Surang juga digunakan untuk mengganti rarepa (ṛ)

Contoh :

Maharsi $=m h \mid i$

- Adeg-adeg '."'।, 
Adeg-adeg memiliki fungsi mengganti tengenan wianjana lainnya. Adegadeg juga dipakai untuk menghindari aksara susun tiga.

Contoh :

Tamblang $=t \mathrm{~m} / \mathrm{b}$

\section{Rangkepan Wianjana}

Rangkepan wianjana maksudnya adalah rangkepan aksara wianjana dengan bentuk gantungan dan gempelan.

\section{- Rangkepan Warga Talawia}

Aksara warga talawia meliputi ca, cha,ja, jha, nya, ya, sa. Kata-kata yang mengandung bunyi na, mendapat gantung ca dan ja, maka na diganti dengan

nya. Contoh: $b \cap k^{6}$ menjadi $b$ z

Kata-kata yang mengandung bunyi sa, mendapat gantungan sa atau sasapa, maka sa diganti dengan sasapa.

Kata-kata yang mengandung bunyi da mendapat gantungan nya, maka da diganti dengan ja.

- Rangkepan Warga Murdania

Aksara warga murdania meliputi ta, tha, da, dha,na, la, sa. Aksara na mendapat gantungan ta latik maka na diganti dengan na rambat.

Contoh : $k$ n Onenjadi $k \times \tilde{0}$

Aksara sa mendapat gantungan ta latik, maka sa diganti dengan sesapa.

Contoh : d $\mathbf{b} \tilde{0}$ menjadi $d[\underline{0}$

Aksara ra diikuti oleh wianjana na dan sa ,maka na diganti dengan na rambat sedangkan sa diganti dengan sesapa.

- Rangkepan Warga Dantia

Aksara warga dantia meliputi ta, tah, da, dha, na,la, sa. 
Contoh :

Hasta $=$ h $s \rho$

Astha $=h S \hat{0}$

- Rangkepan Warga Osthia

Aksara warga osthia meliputi pa, pha, ba, bha, ma, wa.

Contoh :t $\cap \tilde{\theta}$, menjadi $\mathrm{m} \tilde{\theta}$,

Disamping rangkepan aksara tersebut, ada juga ditemukan, rangkepan yang tidak mengikuti aturan warga aksara, yaitu am, ksa. dan rangkepan spa. Kata-kata yang diawali dengan aksara wianjana ba, da, ja, ga apabila mendapat anusuara, masingmasing bentuknya menjadi mba, nda, nyja, ngga.

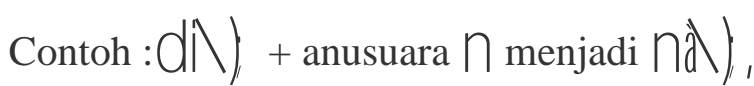

Perulangan duipurwa ditulis dengan aksara legna/legena.

Contoh : Sesate $=$ S S et ,

$$
\text { Lelima }=|| \text { m, }
$$

Kata yang diawali dengan aksara yang mendapat pepet, yang diikuti oleh aksara wianjana lainnya, kecuali aksara ng, mendahului na, maka aksara yang mengikuti menjadi gantungan atau gempelan, dengan menghilangkan pepetnya.

Contoh $=t \mid i$ menjadi et $\tilde{\theta} /$,

\section{E. Penulisan ardasuara}

Berdasarkan fungsinya aksara ardasuara ada empat, yaitu ya, ra, la, wa. Ardasuara sebagai konsonan 
Contoh :

Wayah = Wy i'

Rame $=r e m$,

Ardasuara sebagai vokal

Contoh :

Krana $=k \dot{L}$,

Satua $=$ st ì

Adapun aturan penulisannya adalah sebagai berikut :

- Kata-kata yang suku pertama mendapat suku diikuti bunyi wa, maka wa menjadi suku kembung.

Contoh : $b W_{1,}^{\prime}$ menjadi $b$ j

Kata yang diawali aksara ardasuara ya, atau wa mendapat awalan ka, pa, ma, maka ya menjadi nania, sedangkan wa menjadi suku kembung.

- Kata yang diawali dengan aksara ardasuara mendapat anusuara ng, maka ardasuara menjadi pengangge ardasuara.

Contoh :Wy ${ }_{1}^{*}+1$ I, menjadi $\mid \dot{\varphi} *$,

\section{F. Aksara Maduita}

Aksara maduita maksudnya aksara wianjana yang ditulis rangkap. Aksara maduita yang disebabkan oleh perubahan akar kata menjadi kata. Aksara maduita yang disebabkan oleh surang.

Contoh : 
Dharmma $=V \ln \beta$

\section{G. Tengenan Majalan}

Tengenan majalan maksudnya adalah kata yang berakhir dengan konsonan yang sama, maka disebut tengenan majalan, sehingga konsonan tersebut ditulis hanya

satu. Contoh : S $\hat{\varphi} \mid,+\rho t i$, menjadi $S \hat{\varphi} t i$,

Kemudian kehadiran pasang aksara Bali Schwartz dalam sistem panulisannya, memang membawa perubahan dalam pasang aksara Bali Purwadresta sebelumnya. Hal ini pula yang menyebabkan sistem penulisan bahasa Bali dengan aksara Bali menjadi rancu sehingga dalam penulisannya ada dua macam yaitu mengikuti pasang aksara Bali Schwartz dan tetap menerapkan pasang aksara Bali Purwadresta. Sesungguhnya perbedaan itu wajar-wajar saja, karena kehadiran ejaan Schwartz memang memiliki sasaran menyederhanakan pasang aksara Bali. Beberapa contoh ejaan Schwartz, yaitu sebagai berikut :

- Aksara Suara

$$
\text { Meka }=m k \text {, }
$$

$$
\text { Maisi }=m h \text { ' } j
$$

- Tengenan

$$
\text { Sengkala }=S|/|
$$

$$
\text { Nangka }=\eta \text {, }
$$

- Rangkepan Wianjana

$$
\text { Panci }=p \cap \mathcal{C}_{\mathrm{s}}
$$


Banjar $=b \cap k$

- Semi Vokal (Ardasuara)

Kuah $=k$ ju

Siap $=S \hat{\varphi} /$,

- Muduita

Sarwa $=S W$

- Duipurwa

$$
\text { Sesate }=\text { S S et , }
$$

Uraian tersebut menunjukkan bahwa ejaan Schwartz tidak sejalan dengan tujuan ejaan Purwadresta. Namun dalam pengembangan ejaan Schwartz dapat dikatakan memiliki andil pada masa mendatang.

Lalu setelah ejaan Schwartz muncullah pasang akara Bali tahun 1957 yang maksudnya pasang aksara yang berlaku berdasarkan hasil Pasamuan Agung Bahasa Bali. Di dalam Pasamuan Agung ini masih tetap menerapkan pasang aksara Purwadresta, walaupun ada sedikit penyesuaian untuk kepentingan pengajaran di tingkat pendidikan dasar. Perubahan pasang aksara Bali Schwartz dalam Pasamuan Agung Bahasa Bali tahun 1957, adalah adanya penambahan pamakaian aksara Swalalita dan aksara Modre, serta beberapa perubahan sistem penulisan. Perubahan-perubahan disajikan secara umum, dalam bentuk contoh-contoh sebagai berikut :

- Aksara Suara

$$
\text { Meka }=m k \text {, }
$$


Maisi $=m^{\prime} \delta$

- Tengenan

Sengkala $=s \ \theta$,

Nangka $=n \mid \emptyset$

- Rangkepan Wianjana
Panci $=p Z$
Banjar $=b z \quad b^{\prime}$

- Semi Vokal

Kuah $=k$ j̆

Siap $=S \hat{\varphi} /$,

- Maduita

$$
\text { Sarwa }=S W \mid j
$$

- Duipurwa

$$
\text { Sesate }=\text { S S et , }
$$

Secara umum pasang aksara Bali berdasarkan keputusan hasil Pasamuan Agung Bahasa Bali masih tetap berpedoman pada pasang aksara Purwadresta, karena tujuannya sama yaitu mewariskan nilai-nilai budaya Bali.

Sesuai perkembangan Bahasa Bali terus terjadi perubahan yaitu pasang aksara Bali tahun 1963. Adanya Pasamuan Agung Kecil ini adalah untuk meninjau keputusan Pasamuan Agung 1957, karena dalam keputusan itu masih ada beberapa 
kelemahan, khususnya yang menyangkut pengajaran aksara Bali. Adapun perubahan-perubahan keputusan Pasamuan Agung 1957, di dalam Pasamuan Agung Kecil 1963, hanya menyangkut sistem penulisannya yaitu pasang tumpuk menjadi pasang jajar, atau yang satu kata menjadi dua suku dan juga yang tiga suku menjadi dua suku dalam penulisan dengan aksara Bali yang terkenal dengan sistem dua suku. Sedangkan penggunaan aksaranya masih tetap mempertahankan keputusan Pasamuan Agung 1957.Ada empat perubahan yang ditetapkan dalam Pasamuan Agung Kecil 1963. Perubahan-perubahan itu adalah sebagai berikut :

- Penulisan rangkepan aksara wianjana hanya berlaku dalam satu kata, sedangkan dalam Pasamuan Agung 1957 juga berlaku dalam dua kata Contoh :

Panci $=\rho 2$ T

- Penulisan kata yang menggunakan aksara ardasuara baik yang terdiri atas satu suku maupun tiga suku diubah menjadi dua suku.

Contoh :

Kuah $=k W_{11}^{\prime}$

Buah $=b W_{11}^{\prime}$

- $\quad$ Penulisan aksara muduita hanya mempertahankan maduita yang berasal dari akar kata.

Contoh :

Wrtta $=$ wì

- Penambahan uger-uger, adeg-adeg, yaitu adeg-adeg juga digunakan untuk mempertahankan pasang dan menghindari salah baca.

Contoh : 
Watek ksatria $=w t k / k \times t \frac{f}{f}$,

Empat perubahan yang dilakukan itu tidak sampai mengganggu sasaran utama belajar aksara bali yaitu mewariskan nilai-nilai budaya Bali. Dengan demikian hasil pasamuan Agung Kecil Bahasa Bali 1963 sangat mendukung usaha-usaha pelestarian budaya Bali. Dalam usaha memudahkan pemahaman sistem perubahan penulisan aksara Bali yang terjadi pada setiap periode, maka disajikan perbandingan perubahan yang terjadi secara umum, yaitu sebagai berikut :

- $\quad$ Sistem penulisan Aksara Suara

Purwadresta

Schwartz

1957

1963

$m ‡$<smiles>[AlH2]</smiles>

$m k$,

$m k$,

- Sistem Penulisan Tengenan

Purwadresta Schwartz

1957

1963

$t \mid f t /$,

t $k 0)$ tu

t $\mid$ ft $/$

t $\|$ tu

- $\quad$ Sistem Penulisan Rangkepan Wianjana

Purwadresta Schwartz

1957

1963

$z$ a $\quad b \cap k$

b $Z k$

b $Z k$

- $\quad$ Sistem Penulisan Ardasura

Purwadresta Schwartz

1957

1963

$k P g /$,

$k p g /$

$k \mid 1 g /$

$k|| g /$,

- $\quad$ Sistem Penulisan Aksara Maduita

Purwadresta

Schwartz

1957

1963

$k \not \hat{A}$

$k h$,

$k \not \hat{A}$

$k x$, 
- $\quad$ Sistem Penulisan Duipurwa

Purwadresta Schwartz

Pembicaraan Pasang Aksara Bali 1997 tidak disertakan dalam sub perbandingan Pasang Aksara, karena keputusan Loka Karya Pasang Aksara Bali tahun 1997 hanya bersifat penambahan uger-uger atau aturan-aturan yang memang sebelumnya tidak diatur, terutama menyangkut aturan-aturan penulisan unsur serapan yang berasal dari kata-kat modern.

Adapun keputusan Loka Karya tahun 1997 hanya dilakukan penegasanpenegasan dan beberapa penambahan aturan penulisan yang sebelumnya memang tidak ada, terutama yang menyangkut sistem penulisan singkatan modern. Keputusan hasil Loka Karya Aksara Bali antara lain sebagai berikut.

- Unsur serapan yang berasal dari kata-kata asing kecuali unsur serapan dari kata-kata bahasa Sansekerta dan Jawa Kuna atau bahasa Kawi ditulis dengan menggunakan aksara wrestra atau a, na, ca, ra, ka, ga, ta, ma, nga, ba, sa, wa, la, pa, da, ja, ya, nya. Dengan aksara suaranya beserta pangangge aksaranya dengan sistem penulisan masing-masing.

- Pelafalan unsur serapan modern bunyi a /a/ pada akhir kata, yang tidak umum diucapakn atau dilafalkan e /a/, masih tetap diucapakan a /a/.

Contoh : Lomba dilafalkan /lomba/

- Nama tempat di bawah ini sistem penulisannya berasal dari dua kata.

Contoh : plp i

- Lafal e /a/ pada suku pertama pada kata-kata yang berasal dari ranah tradisional ditulis dengan menggunakan pepet.

Contoh : k t mn/,

- Lafal e /e/ pada suku pertama kata-kata yang berasal dari ranah modern ditulis dengan menggunakan pepet. 


\section{Contoh : S \&K | i}

- Penulisan tingkatan modern dalam pasang aksara Bali adalah menulis ucapannya yang diawali dan diakhiri dengan cari siki.

$$
\text { Contoh:pł \&́/, }
$$

Dalam buku pedoman pasang Aksara Bali Dinas Kebudayaan Provinsi Bali, terdapat beberapa aturan penulisan. Hal tersebut dapat dilihat pada gambar 2.1 dan 2.2.

$$
\begin{aligned}
& \text { rangkepan } \underset{\mathrm{G}}{\mathrm{ml}}=n y j a \rightarrow n j a \text { miwah } \\
& m b_{1}=n y c a \rightarrow n c a, \text { upami } \\
& \text { sanja }=2 \operatorname{mol}_{\text {panca }}=\text { umpl }
\end{aligned}
$$

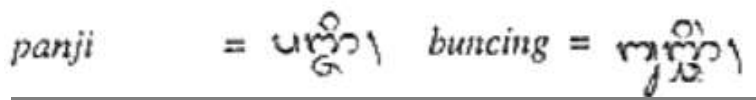

Gambar 2.1 Pasang Aksara Wianjana Warga Talawia

$$
\begin{aligned}
& \text { rangkepan }{ }_{n \rightarrow n} 1=\text { jnya, upami : }
\end{aligned}
$$

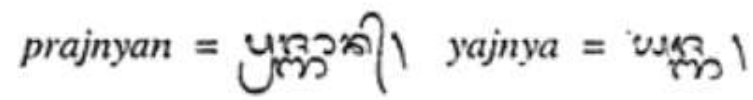

$$
\begin{aligned}
& \text { rangkepan ถู = ssa, upami : } \\
& \text { Dussasana = थुgूวसा } \\
& \text { rangkepan 빈 = sta; } \\
& \text { dusta = ugll wasta = Us }
\end{aligned}
$$

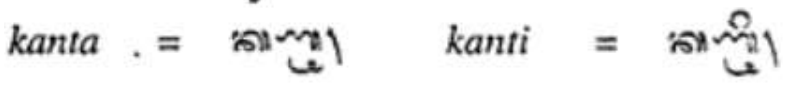

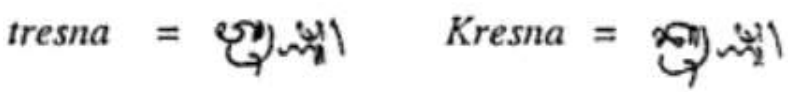

Gambar 2.2Pasang Aksara Wianjana Warga Murdania 


\section{BAB III}

\section{TUJUAN DAN MANFAAT PENELITIAN}

Penelitian ini dilatar belakangi oleh analisis permasalahan yang telah dilakukan. Berdasarkan permasalahan yang telah dirumuskan, tujuan dan manfaat penelitian ini adalah sebagai berikut :

\subsection{Tujuan Penelitian}

Tujuan penelitian ini adalah untuk merancang dan membangun keyboard android aksara Bali, sehingga pengguna android dapat mengetik aksara Bali. Hasil penelitian ini diharapkan dapat membantu pengguna android untuk mengetik aksara (huruf) Bali, sehingga meninggkatkan penggunaan aksara Bali dalam kehidupan keseharian.

\subsection{Manfaat Penelitian}

1. Membantu masyarakat menulis aksara bali yang sesuai dengan aturan pasang aksara bali.

2. Menyediakan sarana untuk menulis aksara bali pada perangkat smartphone khususnya yang menggunakan sistem operasi Andorid.

3. Memberikan kemudahan untuk memperbaiki kesalahan penulisan aksara bali dengan fitur auto correct pada pasang aksara rangkep wianjana warga talawia, murdania dan osthia. 


\section{BAB IV \\ METODE PENELITIAN}

Tahapan Penelitian

Secara garis besar, terdapat dua pekerjaan utama yang dikerjakan dalam penelitian yang dilakukan, yakni perancangan dan pengimplementasian keyboard virtual dengan penambahan fitur auto correct yang menggunakan ketentuan pasang aksara bali pada rangkep wianjana. Gambar 4.1 merupakan tahapan penelitian yang dilakukan.

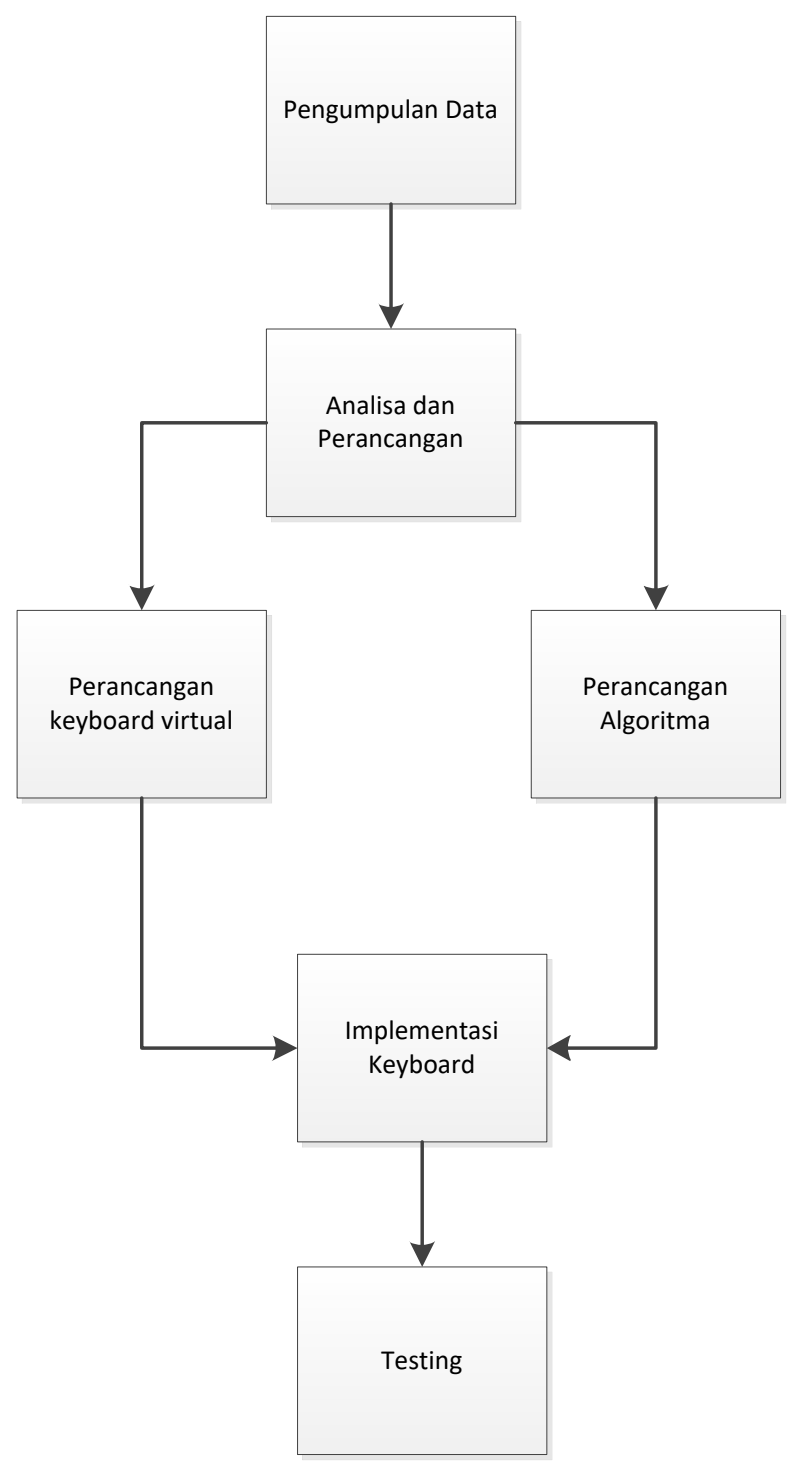

Gambar 4.1 Tahapan Penelitian 
Langkah-langkah penelitian secara garis besar yang dilakukan pada penelitian ini adalah sebagai berikut :

\section{Pengumpulan Data}

Dalam suatu penelitian, langkah pengumpulan data adalah satu tahap yang sangat menentukan terhadap proses dan hasil penelitian yang akan dilaksanakan tersebut. Kesalahan dalam melaksanakan pengumpulan data dalam satu penelitian, akan berakibat langsung terhadap proses dan hasil suatu penelitian. Tanpa data lapangan, proses analisis data dan kesimpulan hasil penelitian, tidak dapat dilaksanakan. Metode pengumpulan data yang dilakukan dalam penelitian ini adalah dengan metode observasi, wawancara, dan studi kepustakaan

\section{Analisa dan Perancangan}

Sebuah aplikasi tentunya harus didukung data-data sebagai sumber informasi dalam melakukan analisa. Hasil analisa kemudian digunakan untuk melakukan perancangan. Analisis yang dilakukan pada penelitian ini adalah tata letak yang memudahkan pengguna dan algoritma auto correct yang berdasarkan aturan pasang aksara bali. Adapun perancangan yang dilakukan adalah:

\section{a. Perancangan aplikasi Keyboard Virtual}

Dasar yang digunakan dalam perancangan keyboard virtual ini adalah keyboard Tamiang. Perbedaan dengan keyboard Tamiang adalah Keyboard virtual yang dibangun, selanjutnya disebut dengan Bali (Bali Ketik), merupakan aplikasi keyboard yang direncanakan berjalan di smartphone dengan sistem operasi Android. Tentunya layout dari keyboard harus memperhatikan ukuran dari smartphone tersebut. Dengan ukuran yang terbatas, penempatan dan pengelompokan aksara akan sangat menentukan tingkat efektifitas dan efisiensi keyboard tersebut.

\section{b. Perancangan Algoritma}

Dari wawancara dan studi literatur tentang pasang aksara bali, penulis melakukan perancangan algoritma auto correct yang menjadi fitur utama dalam penelitian ini. Diharapkan dengan algoritma yang dirancang dapat mempermudah peneliti dalam pengimplementasiannya dalam bahasa pemrograman.

\section{Implementasi aplikasi Keyboard Virtual}


Setelah melalui tahap perancangan, yaitu merancang tata letak dan pengelompokan aksara bali, aplikasi keyboard PaTik Bali diimplementasikan dalam bahasa pemrograman JAVA menggunakan tool Android Studio.

\section{Testing}

Langkah terakhir dalam tahapan penelitian adalah melakukan pengujian (testing).Testing yang dilakukan dalam penelitian ini adalah blackbox testing. Tahapan ini bertujuan untuk melakukan pengecekan dan memastikan masingmasing fungsionlitas dan fitur yang terdapat pada sistem dapat berjalan sesuai dengan perancangan. Tahapan ini termasuk pengembangan sistem (fitur) yang dapat dilakukan kedepannya.

\subsection{Rancangan Penelitian}

Penelitian akan dilakukan dengan menerapkan aplikasi keyboard virtual pada sebuah smartphone android. Sistem Operasi andorid yang digunakan untuk melakukan pengimplementasian keyboard virtual dibatasi dalam versi Kitkat. Gambar 4.2 merupakan rancangan penelitian yang akan dilakukan pada penelitian.

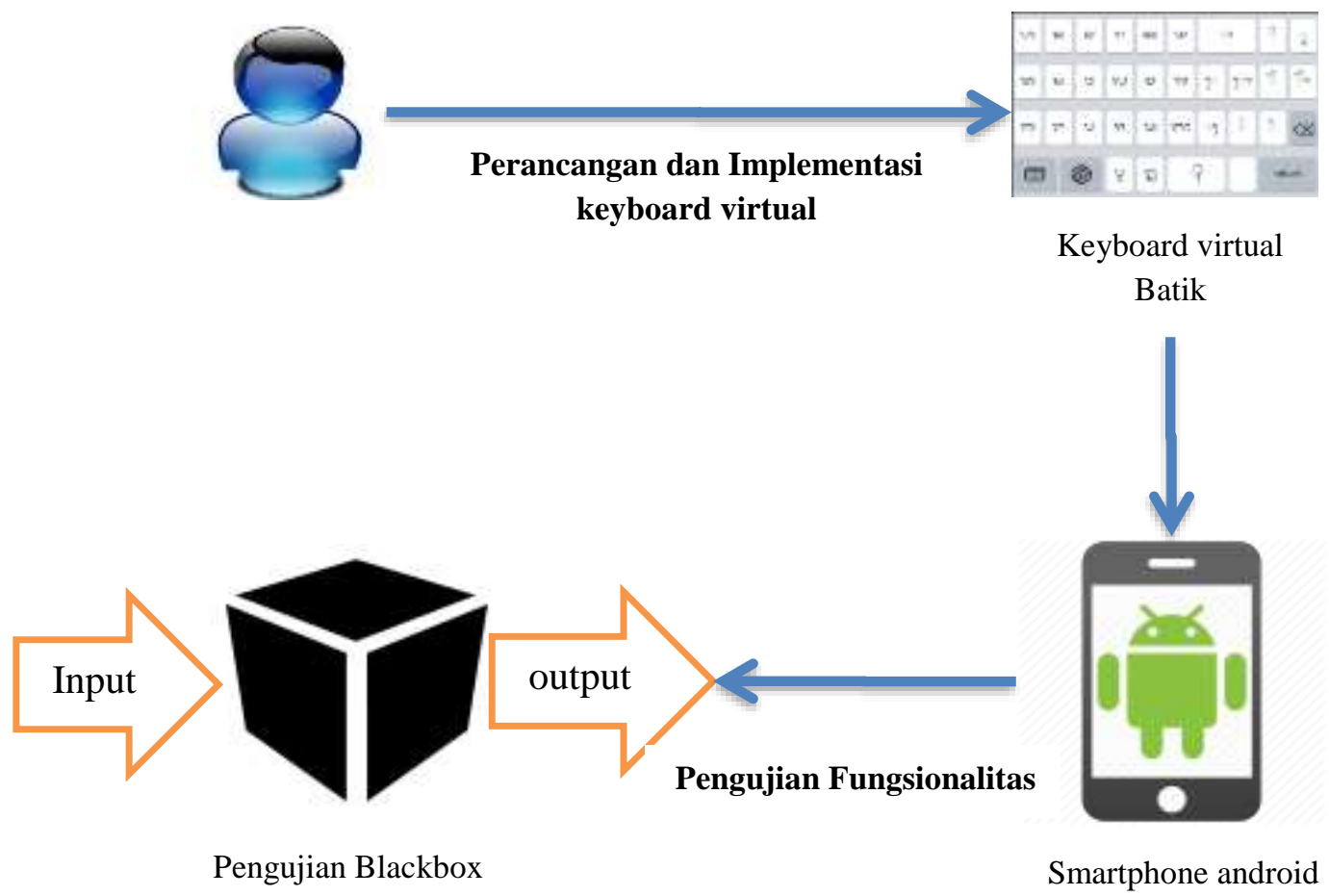

Gambar 4.2 Rancangan Penelitian 
Gambar 4.2 menunjukkan bahwa penelitian direncanakan melalui tiga tahapan utama. Pertama aplikasi keyboard virtual dirancang berdasarkan tata letak dan aturan penulisan aksara bali yang dikenal dengan istilah pasang aksara bali. Perancanganan tersebut direncanakan diimplementasikan dengan bahasa pemrograman JAVA, sehingga aplikasi yang dihasilkan dapat diterapkan pada Sistem operasi android. Pada tahap kedua yang dilakukan adalah melakukan instalasi aplikasi keyboard pada sebuah smartphone. Smartphone yang digunakan sebagai bagian percobaan adalah smartphone dengan merek "Xiao Mi" dengan tipe “Redmi Note 3'. Pengujian akan dilakukan pada fungsionalitas keyboard virtual dengan menggunakan metode black box testing.

\subsection{Teknik Pengumpulan dan Analisis Data}

Pengumpulan data dilakukan dengan studi literatur dan observasi pada objek penelitian.

\section{Observasi}

Observasi merupakan tahapan untuk melihat dan mencermati serta merekam perilaku secara sistematis untuk suatu tujuan tertentu (Herdiansyah, 2010). Pengumpulan data dengan melakukan pengamatan langsung pada papan ketik Tamiang. Observasi yang dilakukan pada papan ketik tamiang bertujuan mempelajari posisi atau tata letak masing-masing jenis huruf pada aksara bali. Pada tahap ini dibantu pula dengan teknik dokumentasi.

\section{Wawancara}

Untuk mengetahui lebih jauh mengenai papan ketik Tamiang, dilakukan wawancara dengan pembuat Tamiang. Sedangkan untuk mengertahui aturan dalam Pasang Aksara, dilakukan wawancara dengan akademisi dan praktisi bahasa Bali, khususnya aksara Bali.

\section{Studi Kepustakaan}

Untuk mendapatkan acuan dan landasan teori yang relevan dengan pembahasan, diperlukan sautu studi kepustakaan mengenai tata letak karakter huruf pada keyboard Tamiang, dan juga aturan mengenai Pasang Aksara yang merupakan aturan dasar dalam penulisan aksara bali. 


\section{BAB V}

\section{ANALISIS DAN PERANCANGAN}

\subsection{Analisa Aplikasi}

Setelah diadakan pengamatan terhadap objek penelitian yaitu keyboard tamiang, ditemukan permasalahan bahwa keyboard Tamiang masih berbentuk keyboard fisik yang digunakan pada personal komputer. Keyboard Tamiang belum memiliki versi virtual yang dapat digunakan atau diinstal pada perangkat komputer maupun android. Karakter dari aksara Bali memiliki jumlah yang melebihi jumlah tombol yang tersedia pada layout keyboard QWERTY, sehingga dalam penggunaannya memerlukan bantuan tombol kontrol ("ctrl") dan "shift". Dengan menggunaan bantuan tombol "ctrl" dan "shift" masing masing tombol pada keyboard QWERTY dapat menampung dua dan paling banyak tiga karakter aksara Bali.

Permasalahan lain yang muncul ketika menggunakan keyboard Tamiang adalah kapan menggunakan kombinasi tombol "ctrl" dan "sift". Terdapat beberapa aturan khusus untuk menggunakan beberapa karakter aksara bali. Tentunya pengguna awam harus mempelajari aturan keyboard Tamiang untuk dapat menggunakannya. Kondisi tersebut yang harus digunakan sebagai acuan dalam merancang dan mengimplementasikan keyboard virtual aksara Bali yang akan dinamakan "PaTik Bali".

Terdapat dua keunggulan dari keyboard "PaTik Bali" yang akan dibangun, keunggulan tersebut adalah pengelompokan dari aksara wianjana, aksara swalalita, aksara suara, gantungan dan gempelan, serta kumpulan pengangge. Untuk pengelompokan karakter dari masing-masing kelompok aksara akan dibahas lebih lanjut pada poin 5.2 tentang perancangan layout dari keyboard "PaTik Bali". Keunggulan kedua adalah adanya fitur untuk memperbaiki kesalahan penulisan aksara bali yang disebut dengan istilah autocorrect. Untuk dapat melakukan perbaikan atas kesalahan pengetikan tulisan yang diakibatkan kesalahan dari penulis, perlu dilakukan pendekatan algoritma terhadap aturan Pasang Aksara Bali. 


\subsection{Perancangan Keyboard Virtual "PaTik Bali"}

Perancangan keyboard virtual ini dipisahkan pada dua tahapan yaitu perancangan layout keyboard dan pendekatan algoritma Pasang Aksara Bali.

\subsection{Perancangan Layout Keyboard}

Rancangan layout keyboard "PaTik Bali" dirancang dengan mengadopsi konsep layout keyboard Tamiang. Hal tersebut didasari oleh rancangan keyboard Tamiang yang memperhatikan frekuensi kemumculan aksara Bali dalam suatu artikel bahasa bali jika dilihat dari karakter latin yang digunakan. Berdasarkan penelitian yang dilakukan Paramartha dan Dwidasmara (2014), penempatan huruf aksara bali diatur menjadi 5 layer. Konsep layer tersebut dapat dilihat pada gambar 5.1 .

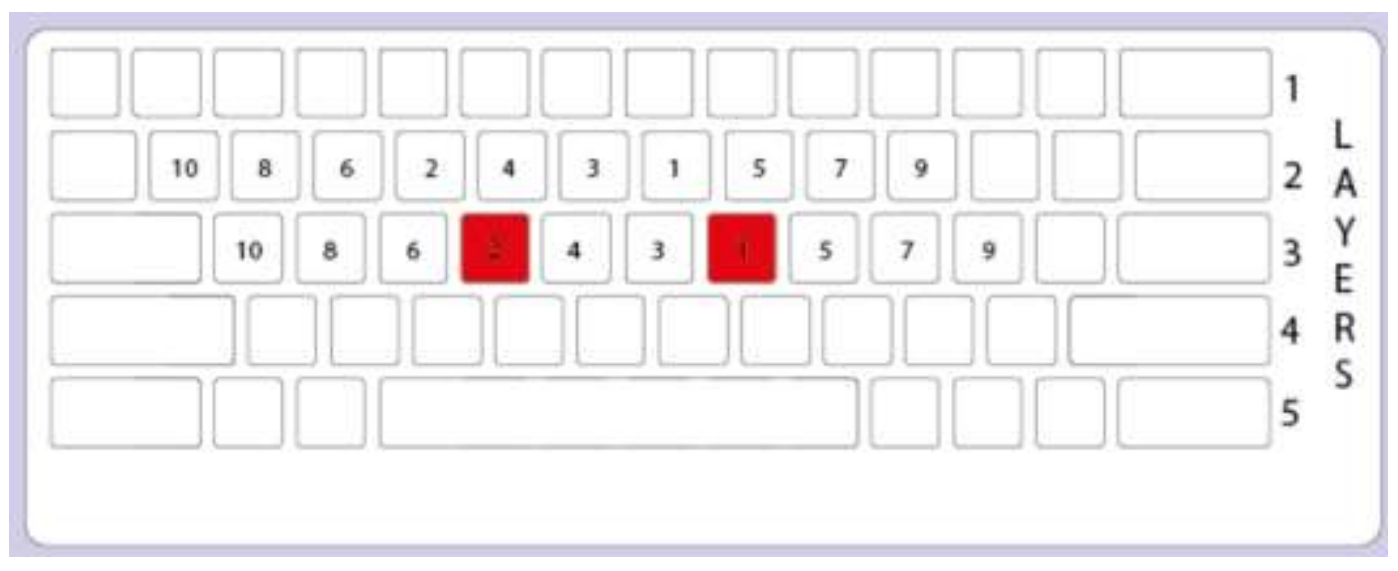

Gambar 5.1 Konsep Layer Keyboard Tamiang

(sumber: Pramartha dan Dwidasmara (2014))

Gambar 5.1 menunjukkan konsep layer pada keyboard Tamiang. Tata letak layer diatur menyesuaikan dengan frekuensi kemunculan huruf dalam sebuah artikel berbahasa Bali. Pada gambar, keyboard dibagi menjadi 5 layer, untuk layer pertama mewakili angka dan tanda baca, layer kedua mewakili konsonan selain huruf "s" dan "n". Hal tersebut karena huruf "s" dan "n" memiliki frekuensi kemunculan paling banyak. Untuk huruf yang memiliki kemunculan yang paling banyak ditempatkan pada layer 3. Berikut merupakan gambar layout dari keyboard "Tamiang Bali". 


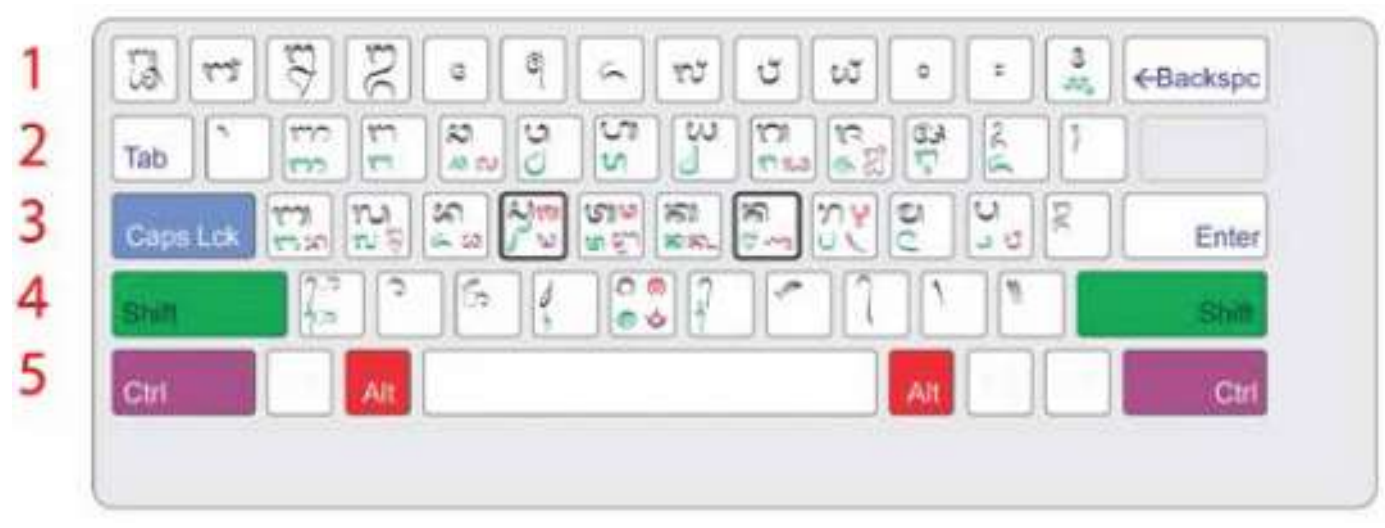

Gambar 5.2 Keyboard Tamiang Bali

(sumber: Pramartha dan Dwidasmara (2014))

Gambar 5.2 menunjukkan layout keyboard "Tamiang Bali”. Berdasarkan gambar tersebut dapat diperhatikan bahwa susunan dari aksara bali diatur sesuai dengan perancangan layout yang ditunjukkan oleh gambar 5.1. Pada gambar 5.2 terlihat pada masing-masing tombol keyboard terdapat lebih dari sebuah karakter. Hal tersebut merupakan pengaruh yang diakibatkan aturan pasang aksara bali. Sesuai dengan pernyataan yang dikemukakan oleh Paramartha dan Dwidasmara (2014), bahwa dalam aturan penulisan aksara bali, masing-masing huruf dapat ditulis dalam bentuk yang berbeda, sesuai dengan aturan yang berlaku untuk kalimat yang ditulis. Namun dalam sebuah tombol keyboard dibatasi maksimal hanya boleh mewakili empat buah bentuk dari sebuah karakter huruf dalam aksara Bali.

Penentuan dasar dalam penempatan karakter dalam aksara Bali pada keyboard "PaTik Bali" yang akan dibangun mengacu atau mengadopsi konsep yang digunakan dalam "Tamiang Bali". Pada "Tamiang Bali", untuk menggunakan bentuk yang berbeda dari sebuah karakter huruf memerlukan bantuan tombol "shift, ctrl, dan alt". Untuk "PaTik Bali", konsep yang diadopsi sebatas penempatan dari masing-masing karakter dengan bentuk lain dari karakter tersebut. Sedangkan untuk dapat memilih bentuk lain dari sebuah karakter tidak memerlukan bantuan tombol "shift, ctrl, dan alt", melainkan menggunakan konsep hold (menahan). Konsep tersebut digunakan untuk memudahkan pengguna dalam memilih bentuk dari sebuah karakter huruf aksara Bali. Untuk keyboard "PaTik Bali" dapat dilihat pada gambar 5.3. 

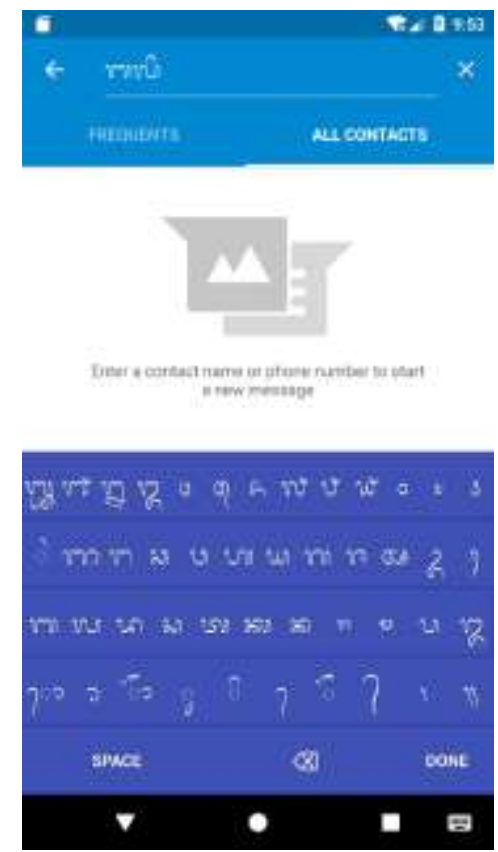

Gambar 5.3 Keyboard PaTik Bali

Pada gambar 5.3 menunjukkan bahwa susunan keyboard "PaTik Bali" disesuaikan dengan tata letak karakter huruf aksara Bali pada keyboard "Tamiang Bali”. Konsep hold yang dimaksud pada keyboard ini adalah ketika pada keyboard "Tamiang" kita harus menekan tombol "shift" atau "ctrl" maupun "alt" untuk menggunakan karakter huruf "na rambat" yang mewakili huruf "na" pada keyboard "PaTik Bali" cukup hanya dengan menahan tombol "na" dalam periode 2 detik. Kemudian akan muncul pop up pilihan varian bentuk lain dari huruf "na" seperti "nanya" dan "na rambat". Hal tersebut tentu akan mempermudah pengguna karena tidak perlu memikirkan tombol apa yang digunakan ketika menginginkan bentuk lain dari huruf tertentu, cukup hanya dengan menahan tombol dari huruf tertentu pada keyboard. Pop up akan memberikan pilihan beberapa bentuk dari karakter tertentu. Untuk tampilan proses pemilihan bentuk yang berbeda pada huruf tertentu dapat dilihat pada gambar 5.4.

Gambar 5.4 menunjukkan hasil yang terjadi ketika menahan sebuah tombol huruf pada keyboard PaTik Bali. Contoh yang digunakan adalah dengan menahan tombol huruf "da" pada aksara bali. Hasil yang terjadi adalah muncul bentuk lain dari huruf "da" yaitu dalam aksara bali disebut dengan "da madu". "Da madu" 
diperlukan ketika pada penulisan sebuah kata terdapat huruf h setelah huruf "d" seperti "dharma" yang merupakan salah satu bentuk aturan pasang aksara.

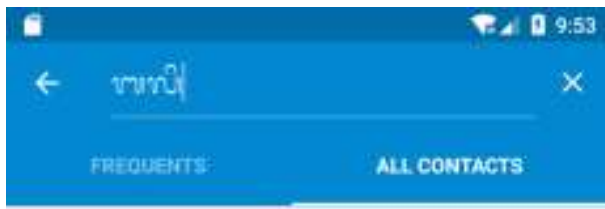

Enter a contact name or phone number to start a new megsege

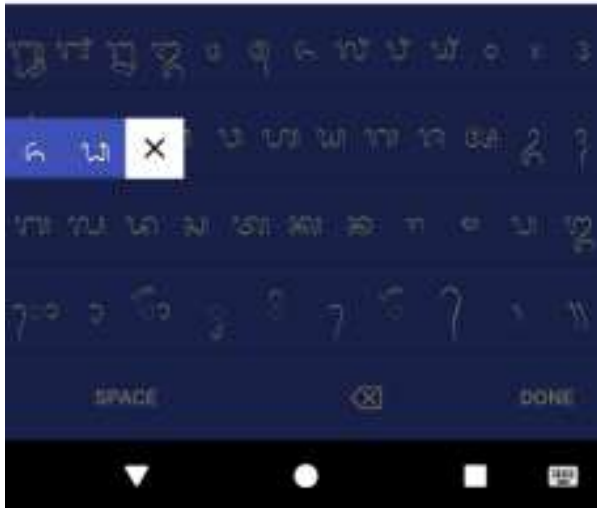

Gambar 5.4 Hasil menahan Tombol pada Keyboard PaTik Bali

Gambar 5.4 menunjukkan popир yang terjadi setelah menekan tombol karakter huruf aksara bali selama 2 detik. Penentuan keyboard menggunkan standard ASCII. Untuk kode masing-masing aksara bali dapat dilihat pada gambar standard ASCII pada gambar 5.5. 


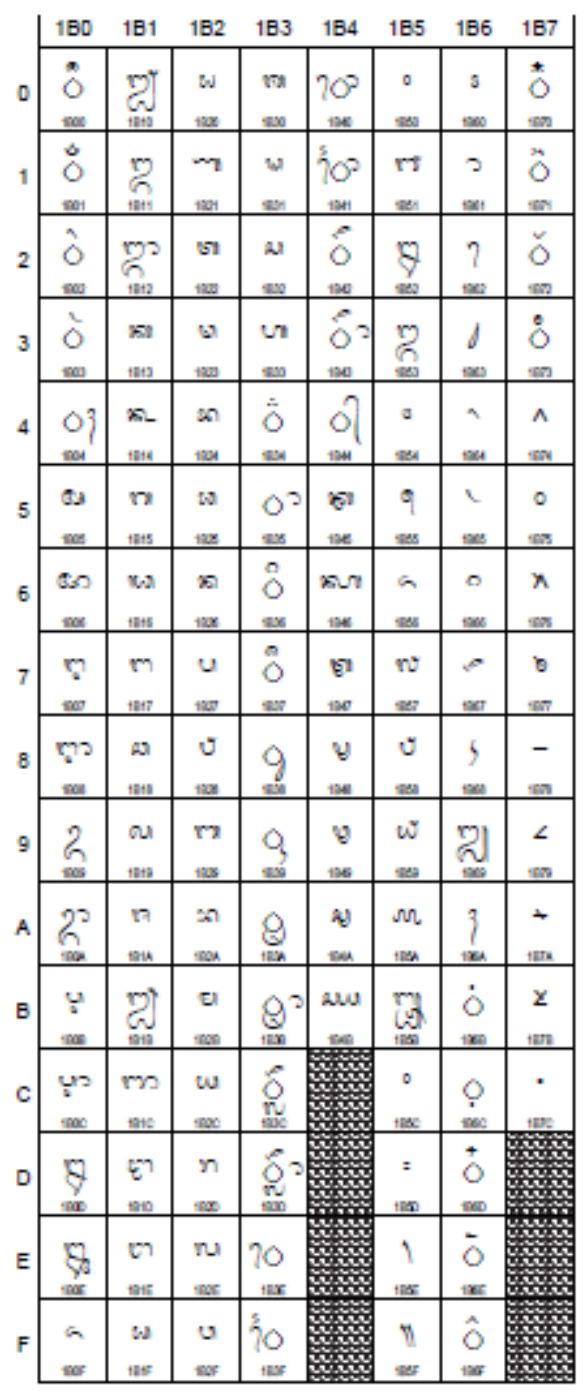

Gambar 5.5 Kode ASCII Aksara Bali

\subsection{Pendekatan Algoritma Pasang Aksara Wianjana}

Dalam melakukan penulisan aksara Bali harus memperhatikan aturan yang disebut dengan pasang aksara Bali. Pasang aksara Bali memiliki banyak aturan yang memungkinkan penulis salah menentukan aksara yang benar yang harus digunakan dalam menulis Bali. Untuk mengantisipasi ketidaktahuan dari penulis awam, maka pada penelitian ini diberikan fitur tambahan yaitu fitur "autocorrect", yang bertujuan memperbaiki tulisan salah yang diketik oleh pengguna "PaTik Bali". Fitur tersebut memerlukan suatu algoritma atau aturan logika yang dibentuk dari pasang aksara Bali. Untuk fitur "autocorrect" dalam penelitian ini masih dibatasi 
dalam Pasang aksara rangkep wianjana. Berikut akan diberikan algoritma pendekatan pasang aksara wianjana:

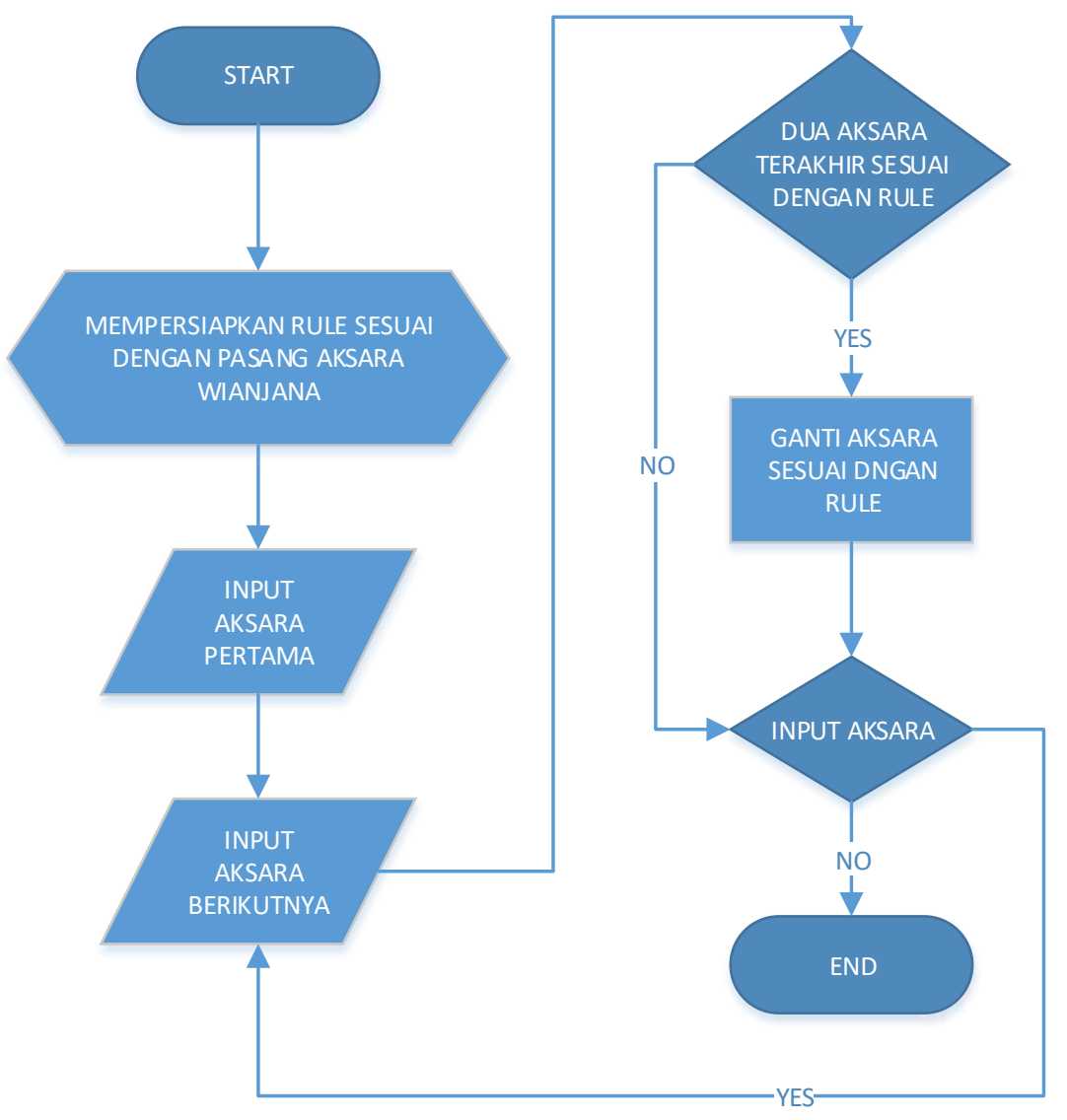

Gambar 5.6 Flowchart Algoritma Autocorrect

1. Start

2. Mempersiapkan rule autocorrect, yang terdiri dari beberapa aturan penulisan aksara bali yang benar menurut pasang aksara wianjana. Adapun aturan tersebut adalah:

a. Warga aksara Talawia: kata-kata yang mengandung bunyi na, mendapat gantungan ca dan ja, huruf na diganti dengan nya. Contoh:

$$
\text { b n }
$$

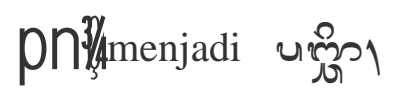




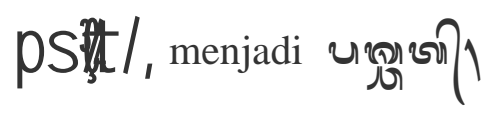 \\ P自敬/, menjadi PÉ}

b. Warga aksara Murdania:

- Kata-kata yang mengandung bunyi na mendapat gantungan tha latik dan dha madu, na diganti na rambat. Contoh:

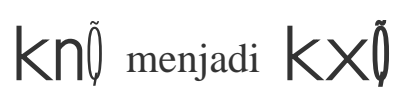

$$
\begin{aligned}
& k \cap 0 \text { menjadik } Z \text { фे. }
\end{aligned}
$$

- Kata-kata yang mengandung bunyi sa mendapat gantungan pa, tha latik dan na rambat, ka mendapat gantungan sa, sa diganti dengan sesapa

$$
d \mathrm{a} \tilde{0} \text { menjadi } d[\tilde{\rho}
$$

$$
\begin{aligned}
& \text { PBæ, menjadi P[J } \\
& \text { k s } \AA \text { menjadi K [ } \AA
\end{aligned}
$$

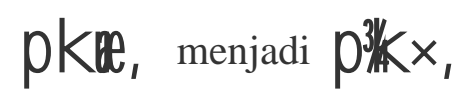

$$
\begin{aligned}
& \text { k } \hat{E} \hat{E} \text { m menjadi } k \hat{E} \hat{E}
\end{aligned}
$$

c. Warga aksara Osthia: Kata-kata yang mengandung bunyi na mendapat gantungan ba, na diganti dengan ma. Contoh: 


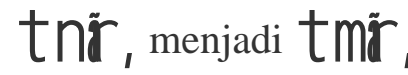

d. Aturan Tambahan: Kata-kata yang mengandung bunyi na mendapat gantungan ba, na diganti dengan ma. Contoh:

$$
\begin{aligned}
& || \delta /, \text { menjadi } \hat{\delta} \mid \delta / \\
& r|m|, \operatorname{menjadi} \mid \mathbf{m} \text {, }
\end{aligned}
$$

rule tersebut dipersiapkan dalam bentuk code yang akan diimplementasikan dalam bahasa JAVA. Rule dibuat pada sebuah class yang sama yang akan digunakan ketika pengguna mulai melakukan penginputan. Rule akan diperiksa ketika pengguna mengetik atau melakukan penginputan huruf atau aksara(onkey).

3. User menginput sebuah huruf atau aksara.

4. Mulai dari inputan kedua aplikasi akan melakukan pengecekan perbandingan dua aksara yang diinputkan dengan rule yang telah disimpan. Jika perbandingan dua buah aksara ada pada rule, maka secara otomatis salah satu aksara akan diganti dengan aksara yang benar sesuai dengan rule.

5. End. 


\section{BAB VI}

\section{HASIL DAN PEMBAHASAN}

\subsection{Antarmuka Sistem}

Aplikasi PaTik Bali dibangun dengan Android Studio. Pada aplikasi tersebut hanya menggunakan sebuah layer antarmuka yang dapat menampung keseluruhan karakter aksara Bali. Antarmuka PaTik Bali dapat ditunjukkan pada gambar 6.1.

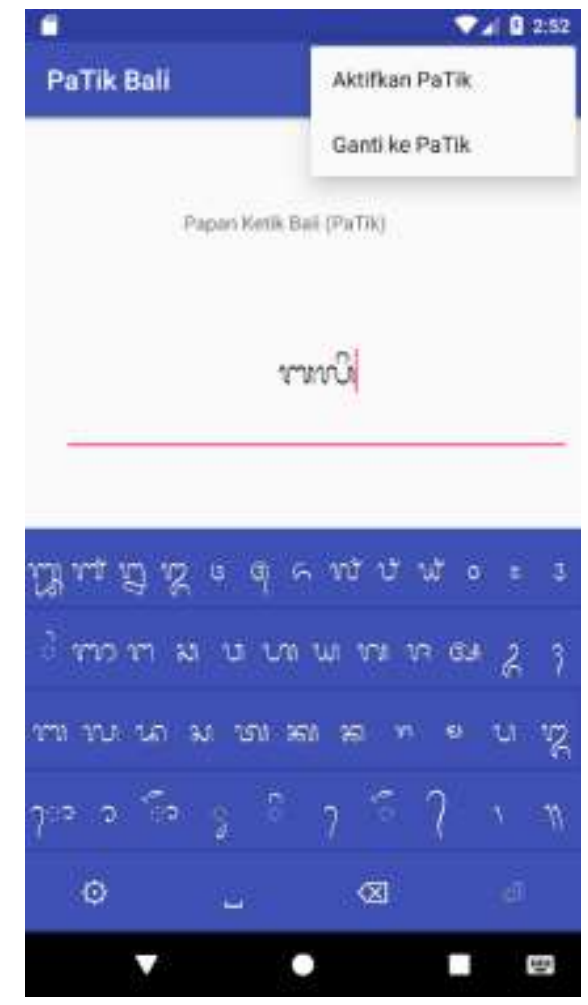

\section{Gambar 6.1 Antar Muka PaTik Bali}

Pada gambar 6.1 rancangan antarmuka aplikasi disesuaikan dengan layout Tamiang Bali yang telah dibahas pada BAB V. Untuk melakukan penginputan masing-masing aksara dilakukan dengan menyentuh layar sesuai dengan aksara yang diberikan. Selain itu terdapat pop up yang digunakan untuk memilih aksara yang sama namun dalam varian berbeda, contohnya ketika ingin memilih aksara na rambat, pengguna perlu menahan layar yang menunjukkan aksana na biasa. Hal tersebut dapat ditunjukkan pada gambar 6.2. 


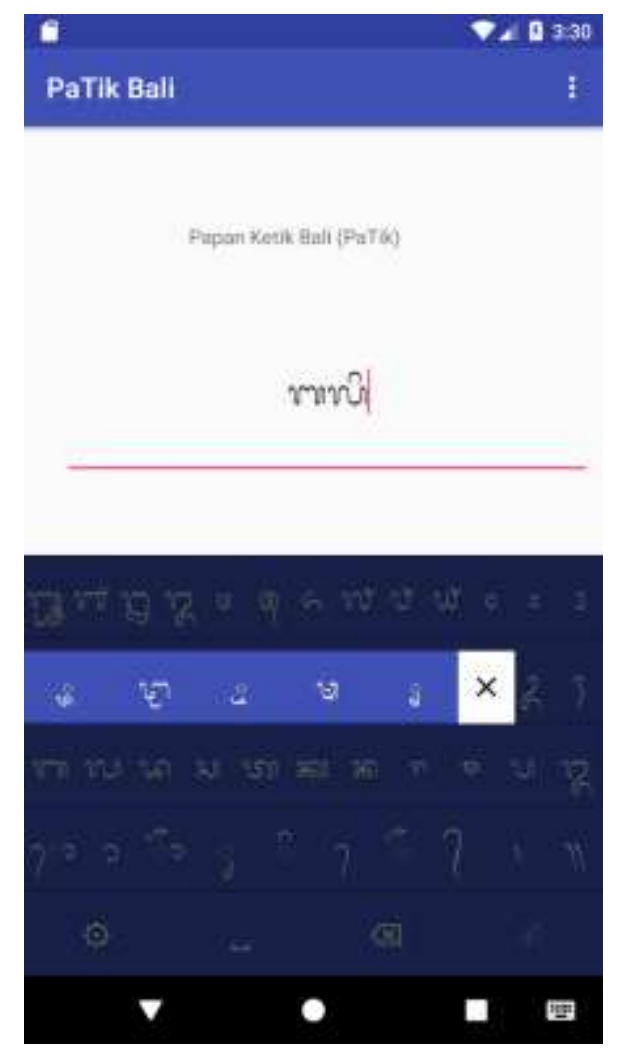

\section{Gambar 6.2 Antarmuka Pop Up pada PaTik Bali}

Pada gambar 6.2 terlihat akan muncul beberapa varian lainnya dari aksara yang dipilih. Hal tersebut bertujuan untuk memudahkan pengguna dalam mencari aksara yang diinginkan. Pengguna tidak perlu lagi menggunakan tombol tambahan seperti ctrl dan alt seperti yang sudah diimplementasikan pada keyboard Tamiang Bali. Selain itu tujuannya adalah meminimalkan layer yang digunakan, hal tersebut mendukung alasan sebelumnya yaitu memberikan kemudahan kepada pengguna untuk mencari aksara yang diinginkan. Apabila layer yang digunakan lebih dari satu, pengguna belum tentu tahu letak dari aksara yang di cari, apakah di layer pertama atau layer berikutnya.

Selain pop up untuk melihat gantungan yang ada pada PaTik Bali, Keyboard ini dilengkapi dengan fitur yang memudahkan pengguna. Fitur ini adalah sebuah tombol setting yang mampu mengarahkan pengguna untuk memilih keyboard lain. Pembuatan tombol ini memudahkan pengguna dalam hal pindah posisi keyboard, karena dalam proses pengetikan kata di android, mungkin saja kita akan mengkombinasikan antara Aksara Bali dengan huruf latin. Fitur ini dapat diakses 
dari tombol dengan icon gear, setelah dipilih akan muncul pop up, yang berisikan menu pemilihan keyboard seperti yang terlihat pada Gambar 6.3.

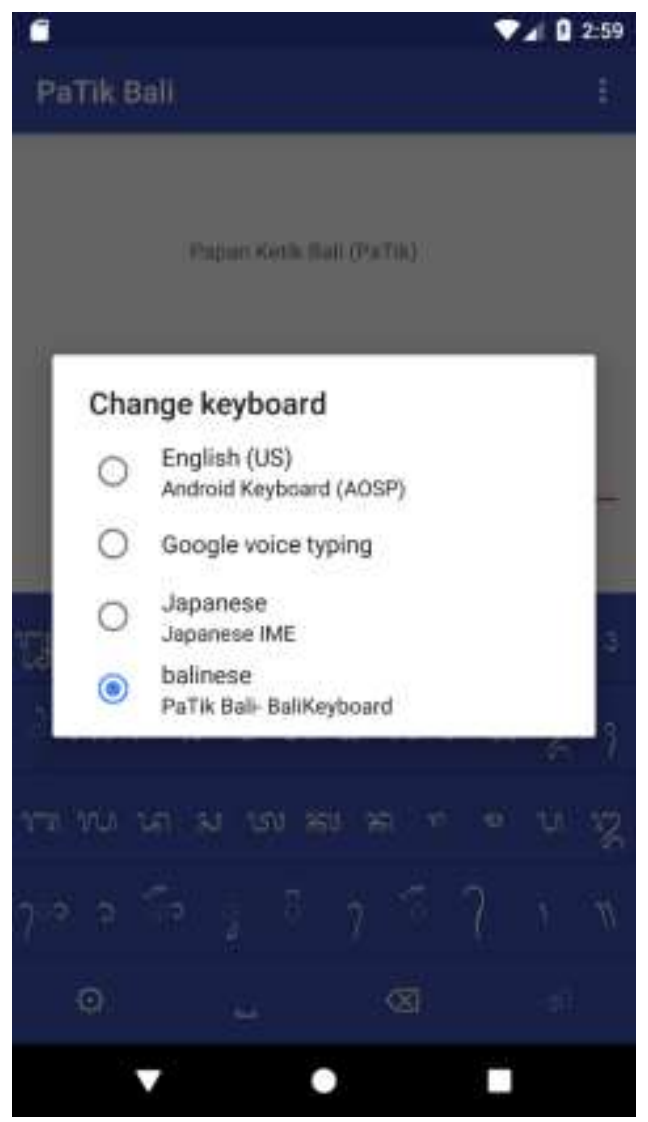

\section{Gambar 6.3Tombol Pengganti Keyboard}

\subsection{Implementasi keyboard PaTik Bali dengan Bahasa JAVA}

PaTik Bali dibangun(diimplementasikan) dengan Android Studio yang memiliki dasar bahasa pemrograman JAVA. Pada android studio, untuk membangun keyboard tamiang menggunakan dua buah class yaitu main activity dan class PaTik. Main activity digunakan untuk membangun template antarmuka keyboard. Sedangkan class PaTik digunakan agar aksara dapat dipilih (onkey). Potongan class main activity dapat dilihat pada gambar 6.4. 


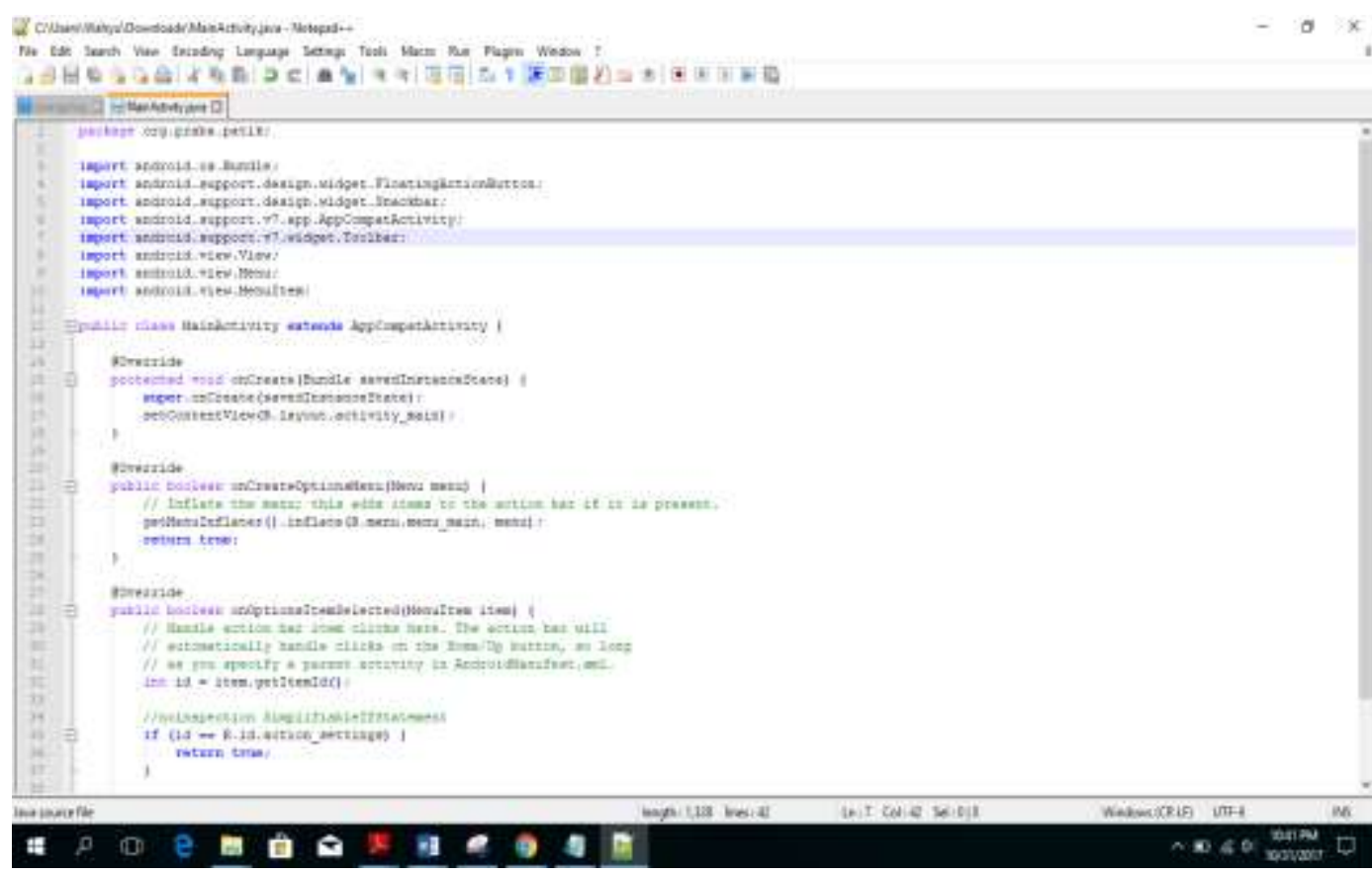

Gambar 6.4 Source Code class Main Activity

\subsection{Pasang Aksara Wianjana pada PaTik Bali}

Fitur autocorrect yang disediakan pada PaTik Bali mengadaptasi aturan pasang aksara wianjana yang telah dibahas pada Bab IV. Untuk menerapkan algoritma tersebut maka pada implementasinya dibuatkan aturan untuk membandingkan dua karakter aksara bali. Untuk kode perbandingkan dua buah karakter tersebut ditunjukkan pada gambar 6.5. Method yang digunakan untuk menentukan dua buah karakter ditunjukkan pada kode public void onText(CharSequence baruInput). Pada method tersebut akan dibandingkan karakter berdasarkan letak kursor. Apabila di depan posisi kursor belum terdapat karakter maka karakter yang diinput akan langsung dimunculkan tanpa melalui pengecekan aturan pasang aksara wianjana. Jika terdapat karakter aksara sebelum kursor, maka karakter pada posisi di depan dan belakang kursor tersebut akan dicocokkan pada aturan pasang aksara bali. Apabila memenuhi salah satu aturan maka salah satu karakter tersebut akan diganti sesuai dengan aturan pasang aksara wianjana. 


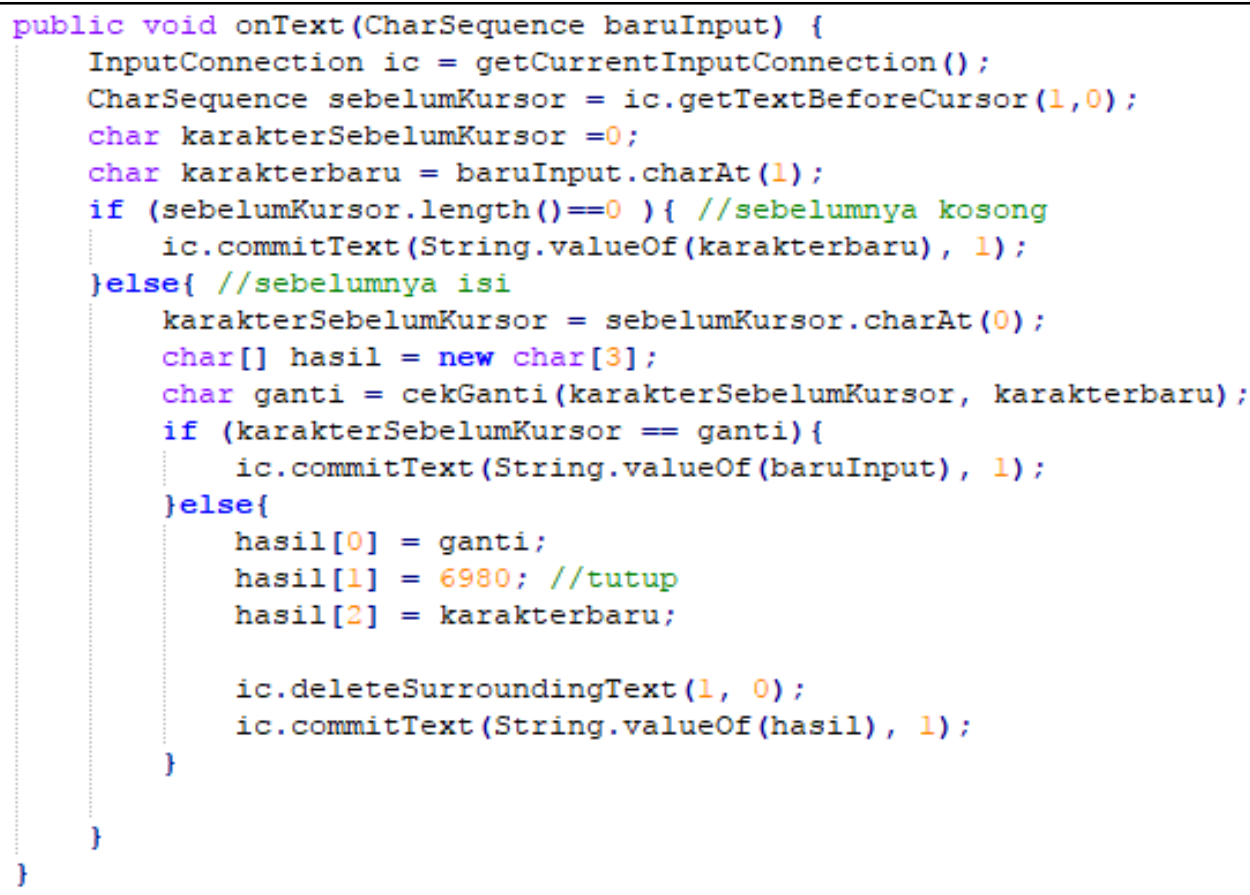

\section{Gambar 6.5Kode Method Perbandingan Dua Karakter}

Pada gambar 6.5 dapat dilihat bahwa penerapan perbandingan dua karakter tersebut menerapkan konsep If then. Hal tersebut merupakan konsep dasar yang telah dipergunakan dalam algortima dan pemrograman untuk melakukan pengecekan terhadap suatu kondisi. Kondisi untuk membandingkan karakter pada program adalah dengan memperhatikan aksara Bali. Masing-masing karakter tersebut memiliki Unicode. Kode Unicode tersebut kemudian diubah menjadi bilangan decimal untuk dibandingkan.

Pasang aksara wianjana dalam aksara Bali memiliki beberapa pola. Pola yang tersebut dituangkan dalam algoritma yang telah dijelaskan pada Bab IV. Pada implementasi dalam bahasa JAVA algoritma tersebut dituangkan dengan konsep switch case. Penggunaan switch case ditentukan berdasarkan kondisi yang diperhitungkan. Switch case lebih tepat digunakan dibandingkan dengan if then untuk pengimplementasian algoritma pasang aksara wianjana karena kondisi yang diperhatikan dalam algoritma pasang aksara adalah perbandingan antara dua buah karakter yang berurutan. Salah satu karakter yang dibandingkan akan diubah sesuai dengan rule atau aturan pasang aksara wianjana. Pada aturan pasang aksara wianjana, terdapat beberapa karakter yang menjadi nilai penentu untuk perubahan 
aksara. Melihat permasalahan tersebut, kondisi yang diperhatikan hanya satu saja yaitu membandingkan sebuah kondisi, namun memiliki banyak nilai yang dilihat, hal tersebut merupakan keunggulan konsep switch case dibandingkan if then. Potongan kode program yang digunakan dalam penelitian ini dapat dilihat pada gambar 6.6.

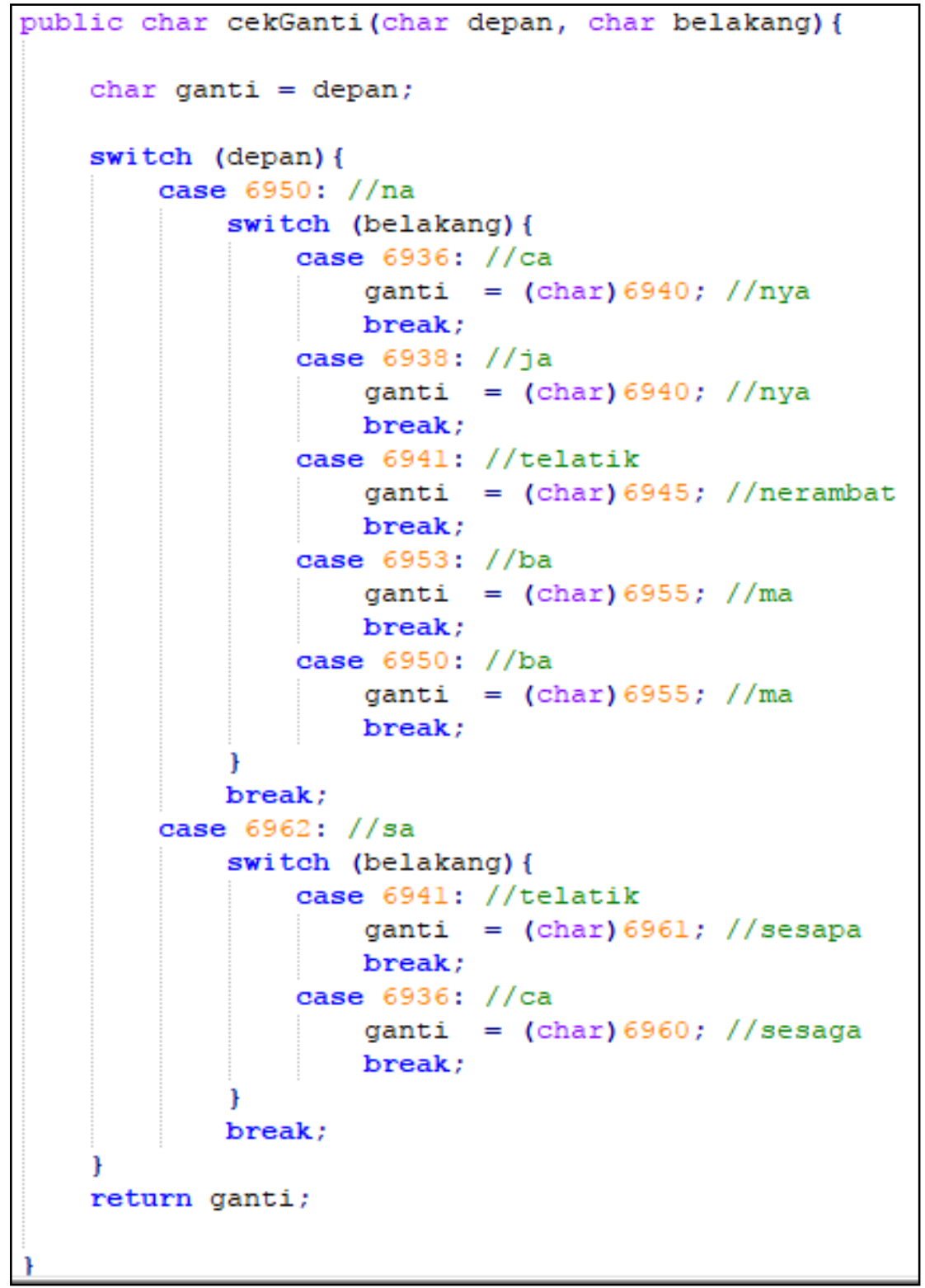

\section{Gambar 6.6 Kode Method Penggantian Karakter}

Penerapan aturan pasang aksara wianjana pada keyboard PaTik Bali yang ditunjukkan gambar 6.6 menggunakan switch bersarang. Penerapan pada method cekGanti tersebut memperhatikan tiga pola. Pola pertama adalah mengganti 
karakter depan dengan karakter pada aturan pasang aksara wianjana, demikian pula dengan pola kedua, namun yang diganti adalah karakter bagian belakang. Sedangkan untuk pola ketiga sedikit berbeda, pola ketiga adalah aturan yang menghapus kedua karakter yang dibandingkan kemudian mengganti karakter yang dihapus tersebut dengan karakter baru.

\subsection{Method Perubahan Karakter}

Metode untuk mengganti karakter depan diperlukan pada sebagian besar aturan pasang aksara rangkep wianjana. Pada pasang aksara rangkep wianjana, aturan penggantian karakter dibagi menjadi dua pola, ganti sebuah karakter atau mengganti kedua karakter sekaligus. hal tersebut berlaku untuk warga wianjana yang diamati dalam penelitian, warga Talawia, Murdania dan Osthia. Berikut pada tabel 6.1 diberikan daftar masing masing warga aksara wianjana yang memiliki aturan perubahan karakter.

Tabel 6.1Aturan Pasang Aksara Rangkep Wianjana

\begin{tabular}{|c|c|c|c|c|c|}
\hline No & $\begin{array}{l}\text { Warga } \\
\text { Aksara }\end{array}$ & Huruf & Gantungan & Hasil & Contoh \\
\hline \multirow{4}{*}{1} & \multirow{4}{*}{ Talawia } & \multirow{2}{*}{ na } & $\mathrm{ca}$ & \multirow{2}{*}{$\begin{array}{l}\text { na menjadi na } \\
\text { rambat }\end{array}$} & 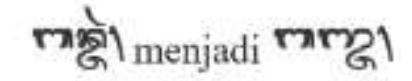 \\
\hline & & & ja & & 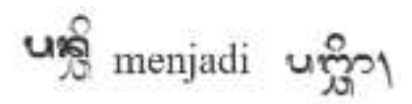 \\
\hline & & $\mathrm{sa}$ & $\mathrm{ca}$ & $\begin{array}{l}\text { sa menjandi sa } \\
\text { saga }\end{array}$ & 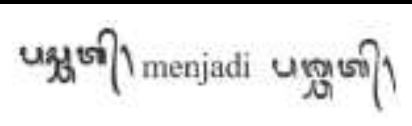 \\
\hline & & da & nya & da menjadi ja & 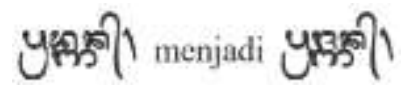 \\
\hline \multirow{4}{*}{2} & \multirow{4}{*}{$\begin{array}{l}\text { Murdan } \\
\text { ia }\end{array}$} & \multirow{2}{*}{ na } & tha latik & \multirow{2}{*}{$\begin{array}{l}\text { na menjadi na } \\
\text { rambat }\end{array}$} & 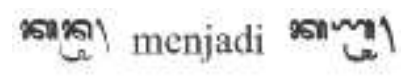 \\
\hline & & & dha madu & & ๙ดू menjadi \\
\hline & & \multirow{2}{*}{ sa } & pha & \multirow{2}{*}{$\begin{array}{l}\text { sa menjadi sa } \\
\text { sapa }\end{array}$} & ชुall menjadi 2 g \\
\hline & & & tha latik & & yall menjadi yux \\
\hline
\end{tabular}




\begin{tabular}{|c|c|c|c|c|c|}
\hline No & $\begin{array}{l}\text { Warga } \\
\text { Aksara }\end{array}$ & Huruf & Gantungan & Hasil & Contoh \\
\hline & & & na rambat & & 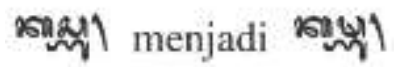 \\
\hline & & ka & sa & $\begin{array}{l}\text { sa menjadi sa } \\
\text { sapa }\end{array}$ & uxght menjadi uxall \\
\hline & & $\mathrm{ra}$ & na & $\begin{array}{l}\text { na menjadi na } \\
\text { rambat }\end{array}$ & 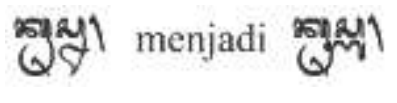 \\
\hline 3 & Osthia & na & ba & na menjadi ma & 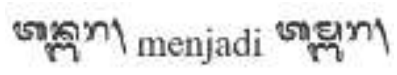 \\
\hline \multirow{2}{*}{4} & \multirow{2}{*}{$\begin{array}{l}\text { Aturan } \\
\text { Tambah } \\
\text { an }\end{array}$} & la & pepet & $\begin{array}{l}\text { la menjadi la } \\
\text { lenga }\end{array}$ & 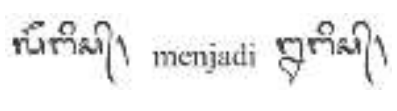 \\
\hline & & ra & pepet & $\begin{array}{l}\text { ra menjadi ra } \\
\text { repa }\end{array}$ & Rarl menjadi yaral \\
\hline
\end{tabular}

Setelah memperhatikan tabel 6.1 sebagian besar aturan pasang aksara wianjana tersebut menggunakan perubahan pada dua buah karakter. Konsep sebuah karakter yang dimaksud adalah: untuk sebuah karakter adalah karakter yang bukan merupakan gantungan pada aksara bali, sedangkan yang dimaksud dengan dua karakter adalah gantungan. Konsep pembentukan gantugan harus terdiri dari huruf tegul dan aksara yang akan diubah menjadi gantungannya. Contoh “".Untuk kode penentuan perubahan karakter dapat dilihat pada gambar 6.7.

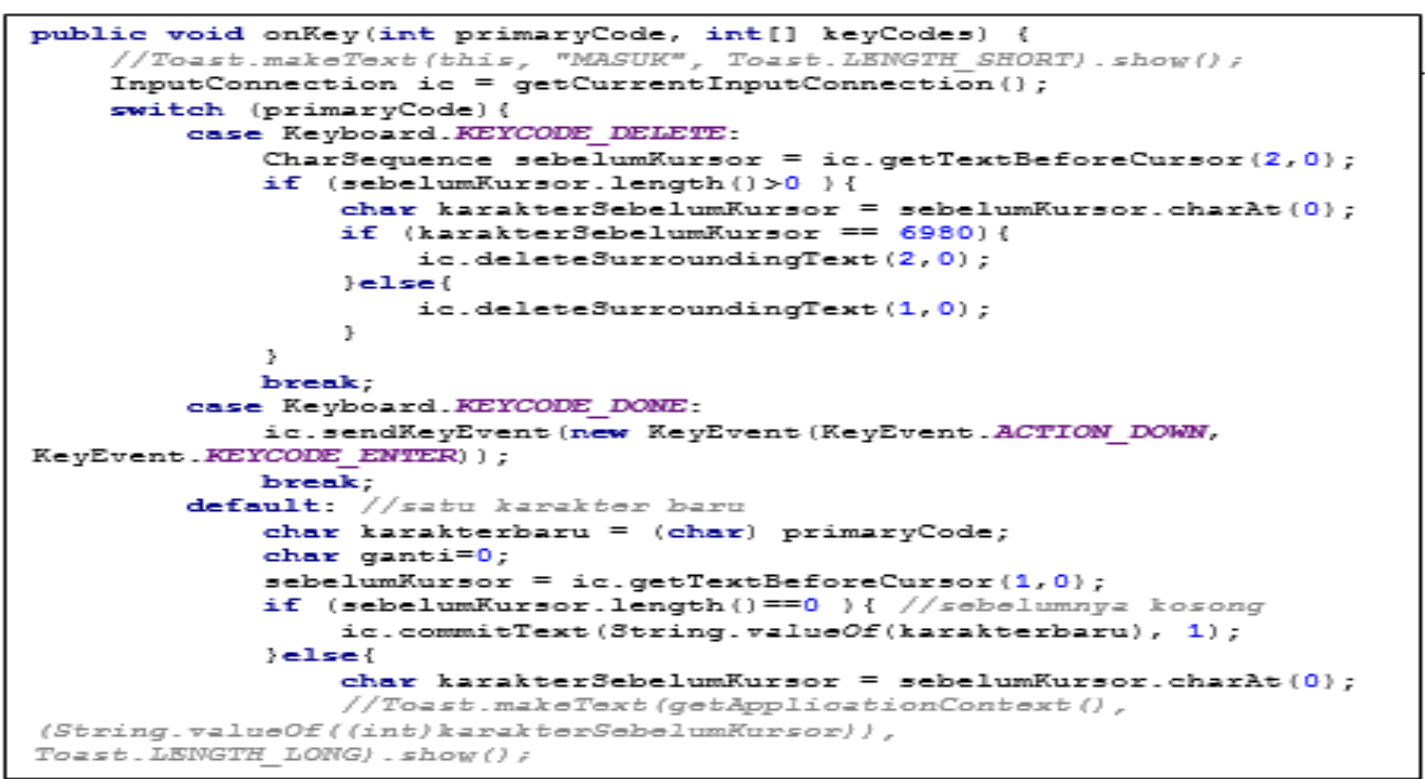




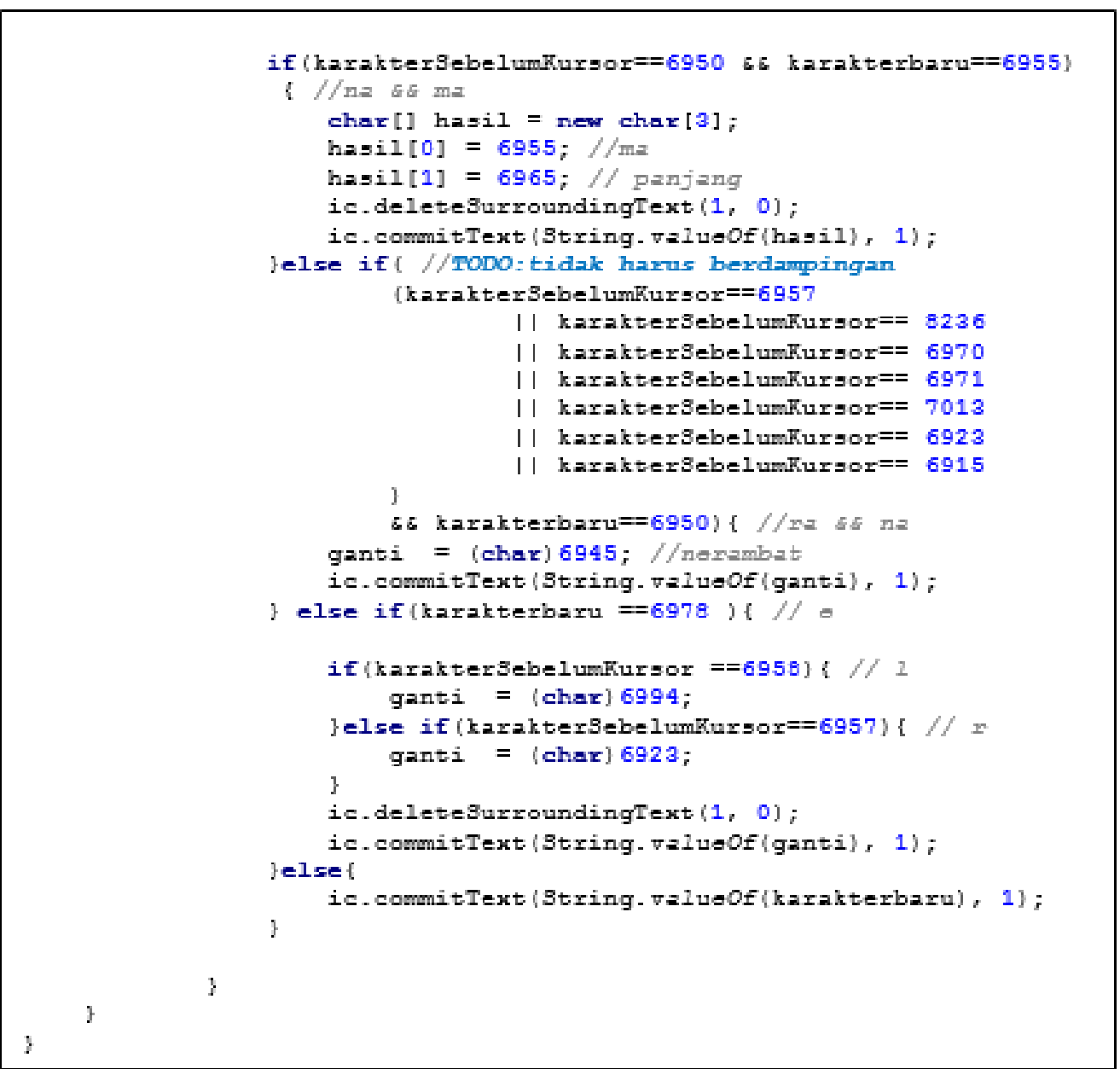

\section{Gambar 6.7Method Perubahan Single Karakter}

Pada gambar 6.7 diberikan method untuk melakukan perubahan pada sebuah karakter yang ditunjukkan dengan code public void onkey(int primarycode, int [] keyCodes). Method tersebut terdiri dari tiga case. Case pertama adalah case Keyboard.KEYCODE_DELETE:, case tersebut berfungsi untuk menghapus karakter. Cara untuk menghapus karakter berbedabeda, ketika aksara bukan merupakan aksara gantung maka yang dihapus adalah sebuah karakter. Sedangkan, ketika aksara merupakan aksara gantung maka yang dihapus adalah dua karakter seperti penjelasan sebelumnya. Case kedua case Keyboard.KEYCODE_DONE:, berfungsi untuk membuat "enter". Case ketiga yaitu default:, berfungsi untuk pasang aksara aturan tambahan yaitu untuk membentuk "lelenga" dan "rerepa". Hal tersebut ditunjukkan pada code berikut if(karakterSebelumKursor ==6958)dan else if(karakterSebelumKursor==6957. 
Berdasarkan code tersebut, yang digunakan untuk mengetahui karakter yang harus dirubah adalah dengan melakukan pengecekan terhadap nilai unicode huruf "1(6958)" dan "r(6957)". Huruf tersebut akan berubah apabila la dan ra pada aksara bali digabungkan dengan "pepet" .

Perubahan aksara yang memperhatikan dua buah karakter berarti hanya akan menyeleksi perubahan huruf berdasarkan "gantungan" yang terdapat pada aturan

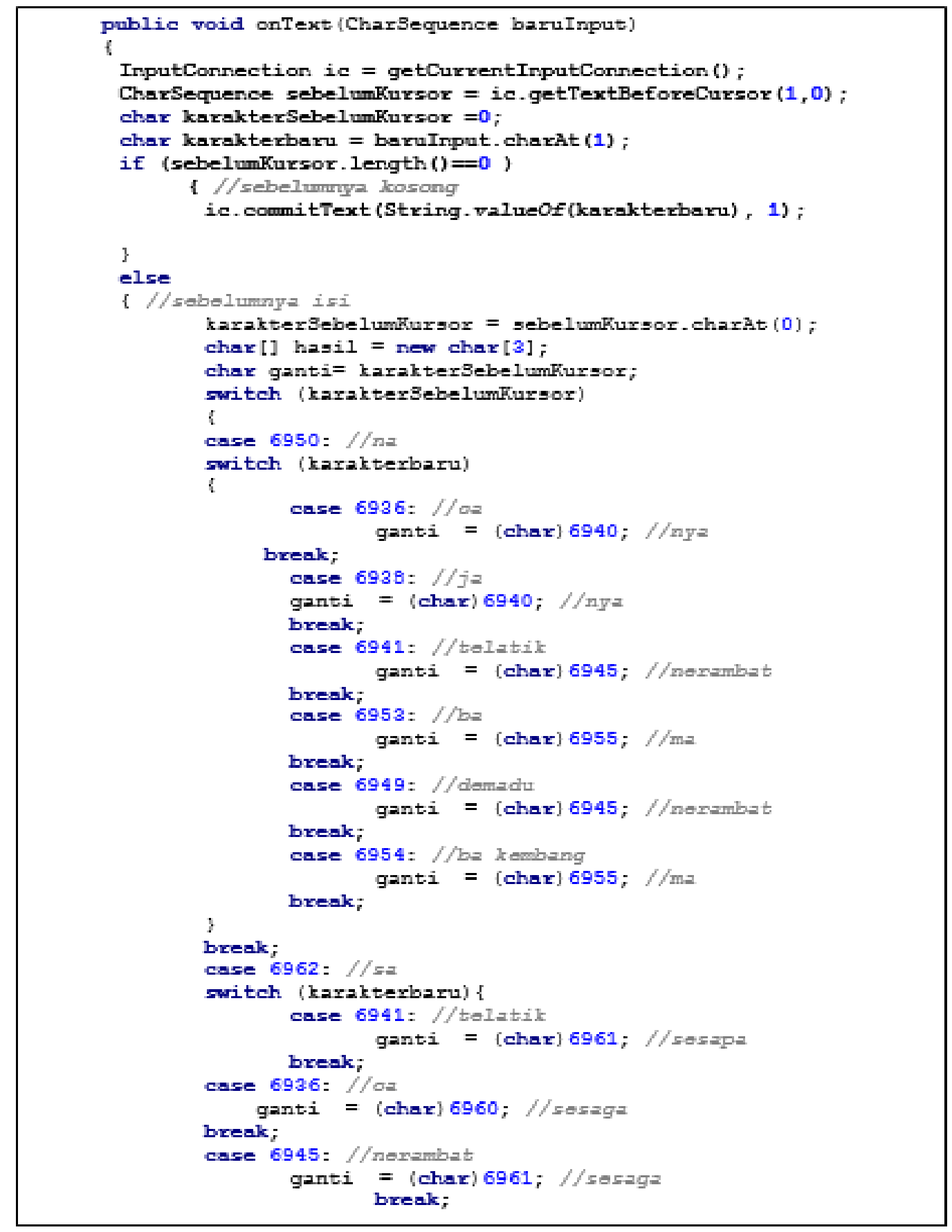




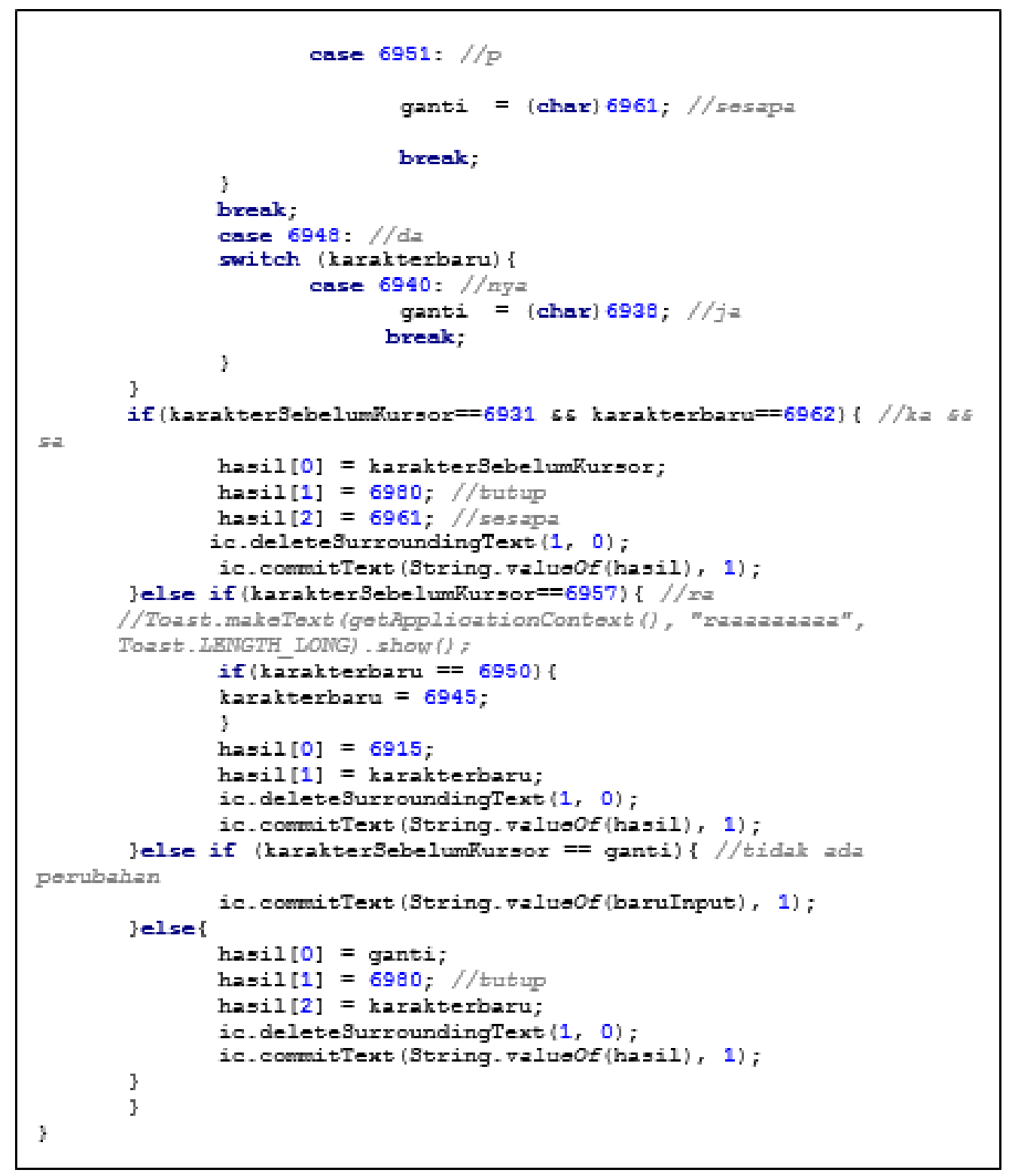

\section{Gambar 6.8 Method Perubahan dua karakter}

pasang aksara Bali rangkep "wianjana”. Untuk code program perubahan dua karater dapat dilihat pada gambar 6.8 .

Pada gambar 6.8 tersebut digunakan untuk mengubah dua buah karakter yang digunakan untuk membentuk sebuah karakter gantungan pada aksara Bali. Dalam membentuk sebuah gantungan pasti memerlukan "tegul". Karakter huruf yang masuk pada aturan ini dalah karakter huruf yang mewakili aksara-aksara Bali dalam aturan pasang aksara wianjana pada tabel 6.1. Cara yang digunakan untuk mengganti karakter tersebut hampir sama dengan aturan perubahan sebuah 
karakter, yaitu dengan memperhatikan unicode karakter yang terdapat pada aturan pasang aksara rangkep wianjana warga Talawia, Murdania, dan Osthia

\subsection{Pengujian Black Box}

Pengujian yang dilakukan pada penelitian ini adalah pengujian black box. Pengujian black box yang dilakukan sebatas pada pengujian fungsionalitas dari aplikasi PaTik Bali. Berikut diberikan hasil pengujian fungsionalitas yang dilakukan pada aplikasi PaTik Bali:

Tabel 6.2Pengujian Black Box PaTik Bali

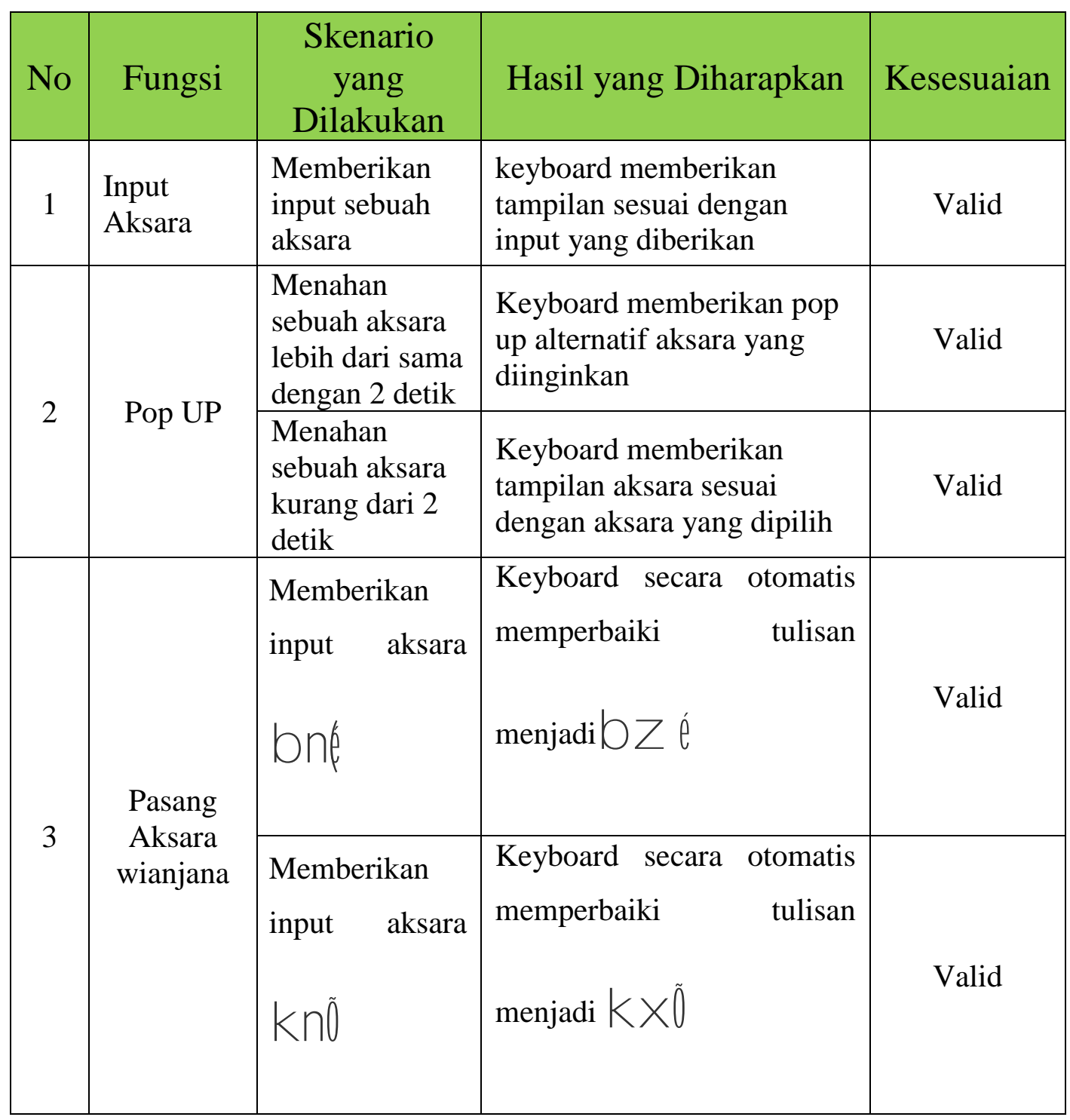




\begin{tabular}{|c|c|c|c|c|}
\hline No & Fungsi & $\begin{array}{c}\text { Skenario } \\
\text { yang } \\
\text { Dilakukan }\end{array}$ & Hasil yang Diharapkan & Kesesuaian \\
\hline & & $\begin{array}{l}\text { Memberikan } \\
\text { input aksara } \\
\text { d } 8 \tilde{O}\end{array}$ & $\begin{array}{l}\text { Keyboard secara otomatis } \\
\text { memperbaiki } \\
\text { menjadi } d[\tilde{0}\end{array}$ & Valid \\
\hline & & $\begin{array}{l}\text { Memberikan } \\
\text { input aksara } \\
\qquad \cap \tilde{\theta}\end{array}$ & $\begin{array}{l}\text { Keyboard secara otomatis } \\
\text { memperbaiki } \\
\text { menjadi t } m \tilde{\theta}\end{array}$ & Valid \\
\hline & & $\begin{array}{l}\text { Memberikan } \\
\text { input aksara di } \\
\text { luar rule }\end{array}$ & $\begin{array}{l}\text { Keyboard tidak memberikan } \\
\text { perbaikan }\end{array}$ & Valid \\
\hline
\end{tabular}

Berdasarkan pengujian yang dilakukan, keseluruhan fungsionalitas dari aplikasi berjalan sesuai dengan scenario yang dirancang. 


\section{BAB VII \\ KESIMPULAN DAN SARAN}

\subsection{Kesimpulan}

Berdasarkan penelitian yang telah dilakukan, maka terdapat beberapa kesimpulan yang didapatkan, yaitu:

1. Perancangan Aplikasi PaTik Bali dilakuan dalam berbagai tahapan yaitu: tahap perancangan keyboard virtual dengan android studio, perancangan algoritma autocorrect, implementasi pada android Kitkat, dan pengujian dengan Black Boxt testing.

2. Berdasarkan pengujian fungsionalitas black box, fitur autocorrect sesuai dengan aturan pasang aksara rangkep wianjana telah berhasil diimplementasikan pada keyboard virtual PaTik.

\subsection{Saran}

Berdasarkan penelitian yang dilakukan, beberapa saran yang dapat diberikan untuk penelitian selanjutnya, yaitu:

1. Diberikan fitur tambahan berupa suggestion untuk kalimat yang dibuat.

2. Memberikan fitur autocorrect dengan keseluruhan aturan pasang aksara bali dan Pasang Pageh. 


\section{DAFTAR PUSTAKA}

Anonim. 2009. Memakai Komputer Bali Simbar Dwijendra.

Bagus, I Gusti Ngurah. 1980. Aksara Dalam Kebudayaan Bali; Suatu Kajian Antropologi. Denpasar : Universitas Udayana.

Gubernur Bali, 2013. Peraturan Gubernur Bali Nomor 20 Tahun 2013 tentang bahasa, aksara dan sastra daerah Bali pada pendidikan dasar dan menengah. Bali.

Kridalaksana, Harimurti. 1993. Kamus Linguistik. Jakarta: Gramedia Pustaka Utama.

Medra, I Nangah. 2002. Pedoman Pasang Aksara Bali. Denpasar : Dinas Kebudayaan Propinsi Bali.

Pramarta, Cokorda Rai Adi and Dwidasmara, I B Gede. 2014. The Composition Approach Non-QWERTY Keyboard for Balinese Script. IEEE. Canada.

Setiyawan, Putu Ary.2014. Balinese Alphabet Sebagai Aplikasi Media Pembelajaran Aksara Bali Berbasis Android Mobile Platform. Jurnal Merpati.

Simpen, I Wayan. 2004. Pasang Aksara Bali. Denpasar : Upasa Sastra

StatCounter.com, Top 8 Desktop, Mobile \& Tablet Operating System in Indonesia $\begin{array}{llll}\text { from april } 2015 \text { to } & 2016\end{array}$ (http://gs.statcounter.com/\#desktop+mobile+tablet-os-ID-monthly201504-201604-bar) di akses tanggal 20 mei 2016

Wilian, Sudirman. 2005. "Bahasa Minoritas, Identitas Etnik, dan Kebertahanan Bahasa: Kasus Bahasa Sumbawa di Lombok." Jurnal Masyarakat Linguistik Indonesia, Februari 2005, Tahun 23, Nomor 1. Jakarta: Masyarakat Linguistik Indonesia Bekerjasama dengan Yayasan Obor Indonesia.

Wirdiani, Ni Kadek Ayu dkk. 2015. Aplikasi Game Edukasi Pasang Pageh Aksara Bali Berbasis Android. Scientific Journal of Informatics 


\section{Lampiran 1. Susunan Organisasi Tim Peneliti dan Pembagian Tugas}

\begin{tabular}{|c|l|l|l|c|l|}
\hline No & Nama/NIDN & $\begin{array}{c}\text { Instansi } \\
\text { Asal }\end{array}$ & Bidang IImu & $\begin{array}{c}\text { Alokasi waktu } \\
\text { (jam/minggu) }\end{array}$ & Uraian Tugas \\
\hline 1 & $\begin{array}{l}\text { Ida Bagus Ary } \\
\text { Indra Iswara, } \\
\text { M.Kom/08240 } \\
48801\end{array}$ & $\begin{array}{l}\text { STMIK } \\
\text { STIKOM } \\
\text { Indonesia }\end{array}$ & $\begin{array}{l}\text { Teknik } \\
\text { Informatika }\end{array}$ & 12 Jam / minggu & $\begin{array}{l}\text { Menganalisis } \\
\text { permasalahan, } \\
\text { mengkoordinasi } \\
\text { kan pengujian. }\end{array}$ \\
\hline 2 & $\begin{array}{l}\text { Putu Praba } \\
\text { Santika, } \\
\text { M.Kom/08151 } \\
28901\end{array}$ & $\begin{array}{l}\text { STMIK } \\
\text { STIKOM } \\
\text { Indonesia }\end{array}$ & $\begin{array}{l}\text { Teknik } \\
\text { Informatika }\end{array}$ & 12 Jam / minggu & $\begin{array}{l}\text { Menganalisis } \\
\text { permasalahan, } \\
\text { merancang dan } \\
\text { membangun } \\
\text { sistem. }\end{array}$ \\
\hline 3 & $\begin{array}{l}\text { I Nyoman } \\
\text { Saputra } \\
\text { Wahyu Wijaya }\end{array}$ & $\begin{array}{l}\text { STMIK } \\
\text { STIKOM } \\
\text { Indonesia }\end{array}$ & $\begin{array}{l}\text { IImu } \\
\text { Komputer }\end{array}$ & 12 Jam / minggu & $\begin{array}{l}\text { Menganalisis } \\
\text { permasalahan, } \\
\text { mengumpulkan } \\
\text { data, menyusun } \\
\text { laporan. }\end{array}$ \\
\hline
\end{tabular}




\section{Lampiran 2. Biodata Ketua dan Anggota}

\section{Ketua Peneliti}

\section{A. Identitas Diri}

\begin{tabular}{|c|c|c|}
\hline 1. & Nama Lengkap & $\begin{array}{l}\text { Ida Bagus Ary Indra Iswara, S.Kom., } \\
\text { M.Kom }\end{array}$ \\
\hline 2. & Jenis Kelamin & Laki-laki \\
\hline 3. & Jabatan Fungsional & Asisten Ahli \\
\hline 4 & NIK & 1403210 \\
\hline 5. & NIDN & 0824048801 \\
\hline 6. & Tempat dan Tanggal Lahir & Bangli, 24 April 1988 \\
\hline 7. & E-Mail & aryindraiswara@gmail.com \\
\hline 8. & Nomor HP & 081805468408 \\
\hline 9. & Alamat Kantor & Jl. Tukad Pakerisan 97 Denpasar, Bali \\
\hline 10. & Nomor Telepon/Faks & $0361-256995 / 0361-246875$ \\
\hline 11. & $\begin{array}{l}\text { Lulusan yang Telah } \\
\text { Dihasilkan }\end{array}$ & 20 \\
\hline \multirow{5}{*}{\multicolumn{2}{|c|}{ 12. Mata Kuliah yg Diampu }} & 1. Struktur Data \\
\hline & & 2. Sistem Operasi \\
\hline & & 3. Jaringan Komputer \\
\hline & & 4. Komunikasi Data \\
\hline & & 5. Pengantar Teknologi Informasi \\
\hline
\end{tabular}

\section{B. Riwayat Pendidikan}

\begin{tabular}{|l|l|l|}
\hline & \multicolumn{1}{|c|}{ S-1 } & \multicolumn{1}{c|}{ S-2 } \\
\hline $\begin{array}{l}\text { Nama Perguruan } \\
\text { Tinggi }\end{array}$ & $\begin{array}{l}\text { Universitas Udayana } \\
\text { (UNUD) }\end{array}$ & $\begin{array}{l}\text { Institut Teknologi Sepuluh } \\
\text { Nopember (ITS) }\end{array}$ \\
\hline Bidang Ilmu & Ilmu Komputer & Teknik Informatika \\
\hline Tahun Masuk-Lulus & 2006-2010 & 2011-2013 \\
\hline $\begin{array}{l}\text { Judul Tugas } \\
\text { Akhir/Tesis }\end{array}$ & $\begin{array}{l}\text { Disain dan } \\
\text { implementasi Internet } \\
\text { Protocol Private Branch }\end{array}$ & $\begin{array}{l}\text { Perbaikan Kinerja Zone } \\
\text { Routing Protocol (ZRP) } \\
\text { Pada MANET Dengan }\end{array}$ \\
\hline
\end{tabular}




\begin{tabular}{|l|l|l|}
\hline & $\begin{array}{l}\text { Exchange (IPPBX) } \\
\text { dengan Menggunakan } \\
\text { Teknologi Voice over } \\
\text { Internet Protocol (VoIP) }\end{array}$ & $\begin{array}{l}\text { Menggunakan Metode } \\
\text { Signal Strength Based Link- } \\
\text { Stability Sensing }\end{array}$ \\
\hline Nama Pembimbing & $\begin{array}{l}\text { 1. } \begin{array}{l}\text { Cokorda Rai Adi } \\
\text { Pramartha, ST, } \\
\text { MMSI }\end{array} \\
\text { Drs. I Wayan } \\
\text { Santiyasa, M.Si. }\end{array}$ & $\begin{array}{l}\text { 1. Wasktho Wibisono, } \\
\text { S.Kom, M.Eng, Ph.D. }\end{array}$ \\
& $\begin{array}{l}\text { 2. } \\
\text { Sal }\end{array}$ \\
\hline
\end{tabular}

\section{Pengalaman Penelitian Dalam 5 Tahun Terakhir}

\begin{tabular}{|c|c|c|c|c|}
\hline \multirow{2}{*}{ No. } & \multirow{2}{*}{ Tahun } & \multirow{2}{*}{ Judul Penelitian } & \multicolumn{2}{|c|}{ Pendanaan } \\
\hline & & & Sumber & Jml (juta Rp) \\
\hline 1 & 2014 & $\begin{array}{l}\text { Analisis Dan } \\
\text { Implementasi Mail } \\
\text { Server Berbasis } \\
\text { Open Source } \\
\text { Software Di Stmik } \\
\text { Stikom Indonesia }\end{array}$ & $\begin{array}{c}\text { Penelitian } \\
\text { Pengembangan } \\
\text { Dosen STIKI } \\
\text { (PPDS) }\end{array}$ & Rp. 3.900.000,- \\
\hline 2 & 2015 & $\begin{array}{l}\text { Analisis Dan } \\
\text { Desain } \\
\text { Infrastruktur } \\
\text { Jaringan Komputer } \\
\text { Di Stmik Stikom } \\
\text { Indonesia }\end{array}$ & $\begin{array}{c}\text { Penelitian } \\
\text { Pengembangan } \\
\text { Dosen STIKI } \\
\text { (PPDS) }\end{array}$ & Rp. 4.980.000,- \\
\hline
\end{tabular}

\section{Pengalaman Pengabdian Kepada Masyarakat dalam 5 Tahun Terakhir}

\begin{tabular}{|l|l|l|l|l|}
\hline \multirow{2}{*}{ No. } & \multirow{2}{*}{ Tahun } & \multicolumn{1}{|c|}{ Judul Penelitian } & \multicolumn{2}{|c|}{ Pendanaan } \\
\cline { 3 - 5 } & 2014 & $\begin{array}{l}\text { Website Pemasaran } \\
\text { Kerajinan Akar Bambu } \\
\text { untuk UKM Akah Bali di } \\
\text { Kabupaten Bangli }\end{array}$ & Institusi & Rp. 3.300.000,- \\
\hline 2. & 2015 & $\begin{array}{l}\text { Pelatihan Microsoft Office } \\
\text { \& Jaringan Bagi Pegawai } \\
\text { Negeri Sipil di Lingkungan } \\
\text { Dinas Perhubungan } \\
\text { Informasi dan Komunikasi } \\
\text { Provinsi Bali }\end{array}$ & Institusi & Rp. 2.200.000,- \\
\hline 3. & 2015 & $\begin{array}{l}\text { Pelatihan 40 Wanita Pelaku } \\
\text { Home Industri Rumah }\end{array}$ & Institusi & Rp. 5.000.000,- \\
\hline
\end{tabular}




\begin{tabular}{|l|l|l|l|}
\hline & $\begin{array}{l}\text { Tangga Dalam Teknologi } \\
\text { Informasi dan Komunikasi } \\
\text { di Denpasar }\end{array}$ & & \\
\hline
\end{tabular}

E. Publikasi Artikel Ilmiah Dalam Jurnal dalam 5 Tahun Terakhir

\begin{tabular}{|c|c|c|c|}
\hline No. & Judul Artikel Ilmiah & Nama Jurnal & Volume/Nomor/Tahun \\
\hline 1. & $\begin{array}{l}\text { Pemilihan Node Tetangga } \\
\text { yang Handal dengan } \\
\text { Memperhitungkan Signal } \\
\text { Strength dan Link Quality } \\
\text { pada Zone Routing Protocol } \\
\text { di Lingkungan MANET }\end{array}$ & $\begin{array}{l}\text { Jurnal Ilmu } \\
\text { Komputer } \\
\text { Universitas } \\
\text { Udayana }\end{array}$ & $\begin{array}{l}\text { Volume VI No } 2 \\
\text { tahun } 2013\end{array}$ \\
\hline
\end{tabular}

F. Pemakalah Seminar Ilmiah (Oral Presentation) dalam 5 Tahun Terakhir

\begin{tabular}{|c|c|c|c|}
\hline No. & $\begin{array}{c}\text { Nama Pertemuan } \\
\text { Ilmiah/Seminar }\end{array}$ & $\begin{array}{c}\text { Judul Artikel } \\
\text { Ilmiah }\end{array}$ & Waktu dan Tempat \\
\hline & & & \\
\hline
\end{tabular}

Semua data yang saya isikan dan tercantum dalam biodata ini adalah benar dan dapat dipertanggungjawabkan secara hukum. Apabila di kemudian hari ternyata dijumpai ketidak-sesuaian dengan kenyataan, saya sanggup menerima sanksi.

Demikian biodata ini saya buat dengan sebenarnya untuk memenuhi salah satu persyaratan dalam pengajuan Penelitian Dosen Pemula

Denpasar, 29 Mei 2016

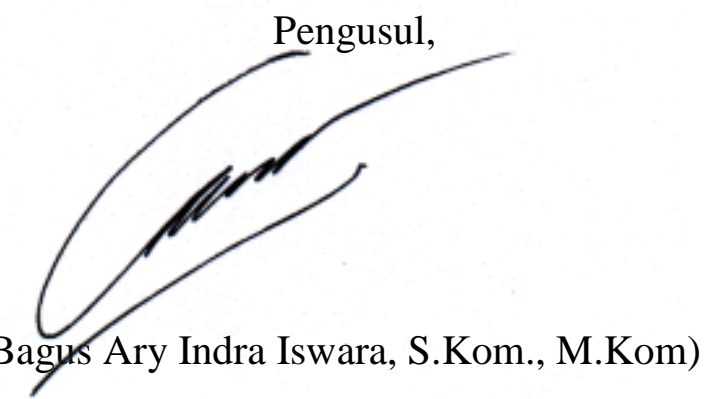




\section{Anggota Peneliti 1}

\section{A. Identitas Diri}

\begin{tabular}{|c|c|c|}
\hline 1. & Nama Lengkap & Putu Praba Santika \\
\hline 2. & Jenis Kelamin & Laki-Laki \\
\hline 3. & Jabatan Fungsional & Tenaga Pengajar \\
\hline 4. & NIK & 1510244 \\
\hline 5. & NIDN & 0815128901 \\
\hline 6. & Tempat dan Tanggal Lahir & Denpasar, 15 Desember 1989 \\
\hline 7. & E-Mail & putu@praba.web.id \\
\hline 8. & Nomor HP & 08180532105 \\
\hline 9. & Alamat Kantor & Jl. Tukad Pakerisan 97 Denpasar, Bali \\
\hline 10. & Nomor Telepon/Faks & $0361-256995 / 0361-246875$ \\
\hline 11. & $\begin{array}{l}\text { Lulusan yang Telah } \\
\text { Dihasilkan }\end{array}$ & - \\
\hline \multirow{4}{*}{\multicolumn{2}{|c|}{ 12. Mata Kuliah yg Diampu }} & 1. Algoritma \\
\hline & & 2. Sistem Basis Data \\
\hline & & 3. Bahasa Basis Data \\
\hline & & 4. Data Integration \\
\hline
\end{tabular}

\section{B. Riwayat Pendidikan}

\begin{tabular}{|l|l|l|}
\hline & \multicolumn{1}{|c|}{ S-1 } & \multicolumn{1}{c|}{ S-2 } \\
\hline Nama Perguruan Tinggi & Universitas Udayana & $\begin{array}{l}\text { Institut Teknologi Sepuluh } \\
\text { Nopember Surabaya }\end{array}$ \\
\hline Bidang Ilmu & Sistem Informasi & Sistem Informasi \\
\hline Tahun Masuk-Lulus & $2007-2012$ & $2013-2015$ \\
\hline
\end{tabular}




\begin{tabular}{|l|l|l|}
\hline Judul Skripsi/Thesis & $\begin{array}{l}\text { Perancangan Dan } \\
\text { Implementasi Rekam Medis } \\
\text { Berbasis Mobile }\end{array}$ & $\begin{array}{l}\text { Pengukuran Tingkat Polaritas } \\
\text { Review Pada Cross-Domain } \\
\text { Sentiment Classification }\end{array}$ \\
\hline \multirow{3}{*}{ Nama Pembimbing } & $\begin{array}{l}\text { IB. Md. Mahendra, S.Kom, } \\
\text { M.Kom }\end{array}$ & $\begin{array}{l}\text { Dr. Agus Zainal Arifin, } \\
\text { S.Kom., M.Kom. }\end{array}$ \\
& $\begin{array}{l}\text { IB. Gede Dwidasmara, } \\
\text { S.Kom., M.Cs. }\end{array}$ & $\begin{array}{l}\text { Diana Purwitasari, S.Kom, } \\
\text { M.Sc }\end{array}$ \\
\hline
\end{tabular}

\section{Pengalaman Penelitian Dalam 5 Tahun Terakhir}

\begin{tabular}{|l|l|l|l|l|}
\hline \multirow{2}{*}{ No. } & \multirow{2}{*}{ Tahun } & Judul Penelitian & \multicolumn{2}{|c|}{ Pendanaan } \\
\cline { 4 - 5 } & & & Sumber & Jml (juta Rp) \\
\hline 1. & & & & \\
\hline 2. & & & & \\
\hline
\end{tabular}

\section{Pengalaman Pengabdian Kepada Masyarakat dalam 5 Tahun Terakhir}

\begin{tabular}{|l|l|l|l|l|}
\hline \multirow{2}{*}{ No. } & \multirow{2}{*}{ Tahun } & Judul Penelitian & \multicolumn{2}{|c|}{ Pendanaan } \\
\cline { 4 - 5 } & & & Sumber & Jml (juta Rp) \\
\hline 1. & & & & \\
\hline 2. & & & & \\
\hline
\end{tabular}

E. Publikasi Artikel Ilmiah Dalam Jurnal dalam 5 Tahun Terakhir

\begin{tabular}{|l|l|l|l|}
\hline No. & \multicolumn{1}{|c|}{ Judul Artikel Ilmiah } & Nama Jurnal & Volume/Nomor/Tahun \\
\hline 1 & $\begin{array}{l}\text { Pembentukan Thesaurus } \\
\text { yang Sensitif Terhadap } \\
\text { Tingkat Polaritas Review } \\
\text { Pada Cross-Domain } \\
\text { Sentiment Classification }\end{array}$ & $\begin{array}{l}\text { Jurnal } \\
\text { Inspiration }\end{array}$ & Vol 5, No 2 (2015) \\
\hline
\end{tabular}




\begin{tabular}{|l|l|l|l|}
\hline 2 & $\begin{array}{l}\text { Perangkingan Dokumen } \\
\text { Berbahasa Arab } \\
\text { Menggunakan Latent } \\
\text { Semantic Indexing }\end{array}$ & $\begin{array}{l}\text { Jurnal Buana } \\
\text { Informatika }\end{array}$ & Vol.6 No.2 April 2015 \\
\hline 3 & $\begin{array}{l}\text { Semantic Clustering Dan } \\
\text { Pemilihan Kalimat } \\
\text { Representatif Untuk } \\
\text { Peringkasan Multi Dokumen }\end{array}$ & $\begin{array}{l}\text { Jurnal Teknologi } \\
\text { Informasi dan } \\
\text { Ilmu Komputer } \\
\text { (JTIIK) }\end{array}$ & $\begin{array}{l}\text { Vol. 1, No. 2, Oktober } \\
\text { 2014 }\end{array}$ \\
\hline
\end{tabular}

F. Pemakalah Seminar Ilmiah (Oral Presentation) dalam 5 Tahun Terakhir

\begin{tabular}{|l|c|c|c|}
\hline No. & $\begin{array}{c}\text { Nama Pertemuan } \\
\text { Ilmiah/Seminar }\end{array}$ & $\begin{array}{c}\text { Judul Artikel } \\
\text { Ilmiah }\end{array}$ & Waktu dan Tempat \\
\hline 1. & & & \\
\hline 2. & & & \\
\hline
\end{tabular}

Semua data yang saya isikan dan tercantum dalam biodata ini adalah benar dan dapat dipertanggungjawabkan secara hukum. Apabila di kemudian hari ternyata dijumpai ketidak-sesuaian dengan kenyataan, saya sanggup menerima sanksi.

Demikian biodata ini saya buat dengan sebenarnya untuk memenuhi salah satu persyaratan dalam pengajuan Penelitian Dosen Pemula

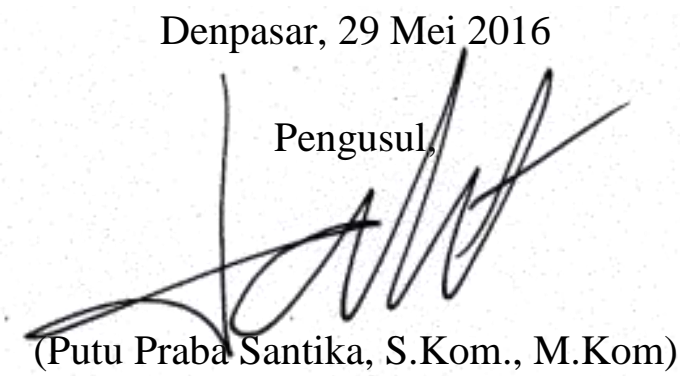


3. Anggota Peneliti 2

A. Identitas Diri

\begin{tabular}{|c|c|c|}
\hline 1. & Nama Lengkap & $\begin{array}{l}\text { I Nyoman Saputra Wahyu Wijaya, S.Kom., } \\
\text { M.Cs }\end{array}$ \\
\hline 2. & Jenis Kelamin & Laki-laki \\
\hline 3. & Jabatan Fungsional & Tenaga Pengajar \\
\hline 4 & NIK & 1509241 \\
\hline 5. & NIDN & 0826108901 \\
\hline 6. & $\begin{array}{l}\text { Tempat dan Tanggal } \\
\text { Lahir }\end{array}$ & Denpasar, 26 Oktober 1989 \\
\hline 7. & E-Mail & Inym.wahyu@gmail.com \\
\hline 8. & Nomor HP & 08174770285 \\
\hline 9. & Alamat Kantor & J1. Tukad Pakerisan 97 Denpasar, Bali \\
\hline 10. & Nomor Telepon/Faks & $0361-256995 / 0361-246875$ \\
\hline 11. & $\begin{array}{l}\text { Lulusan yang Telah } \\
\text { Dihasilkan }\end{array}$ & - \\
\hline \multirow{5}{*}{\multicolumn{2}{|c|}{ 12. Mata Kuliah yg Diampu }} & a. Sistem Basis Data \\
\hline & & b. Struktur Data \\
\hline & & c. Data Integration \\
\hline & & d. Decision Support System \\
\hline & & e. Audit Teknologi Informasi \\
\hline
\end{tabular}




\section{B. Riwayat Pendidikan}

\begin{tabular}{|l|l|l|}
\hline & \multicolumn{1}{|c|}{ S-1 } & \multicolumn{1}{c|}{ S-2 } \\
\hline Nama Perguruan Tinggi & Universitas Udayana & Universitas Gadjah Mada \\
\hline Bidang Ilmu & Ilmu Komputer & Ilmu Komputer \\
\hline Tahun Masuk-Lulus & $2007-2011$ & $2012-2015$ \\
\hline Judul Tugas Akhir/Tesis & $\begin{array}{l}\text { Perancangan dan Implementasi } \\
\text { Automated Text Summarization dengan } \\
\text { Menggunakan Algoritma Dijkstra }\end{array}$ & $\begin{array}{l}\text { Pemodelan dan Evaluasi Formal } \\
\text { Pengaruh Mobility Pattern } \\
\text { terhadap Handoff Latency }\end{array}$ \\
\hline Nama Pembimbing & $\begin{array}{l}\text { 1. Drs. I Wayan Santiyasa, M.Sc } \\
\text { 2. Ngurah Agus Sanjaya E.R., Mkom }\end{array}$ & $\begin{array}{l}\text { 1. Dr.-Ing. MHD. Reza M.I. } \\
\text { Pulungan, S.Si., M.Sc. }\end{array}$ \\
\hline
\end{tabular}

\section{Pengalaman Penelitian Dalam 5 Tahun Terakhir}

\begin{tabular}{|l|l|l|l|l|}
\hline \multirow{2}{*}{ No. } & \multirow{2}{*}{ Tahun } & \multirow{2}{*}{ Judul Penelitian } & \multicolumn{2}{|c|}{ Pendanaan } \\
\cline { 3 - 4 } & & Sumber & Jml (juta Rp) \\
\hline & & & & \\
\hline
\end{tabular}

\section{Pengalaman Pengabdian Kepada Masyarakat dalam 5 Tahun Terakhir}

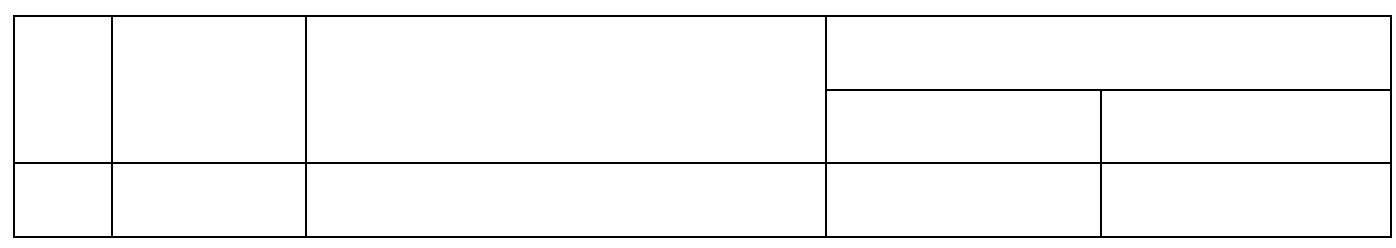

\section{E. Publikasi Artikel Ilmiah Dalam Jurnal dalam 5 Tahun Terakhir}

\begin{tabular}{|c|c|c|c|}
\hline No. & Judul Artikel Ilmiah & Nama Jurnal & Volume/Nomor/Tahun \\
\hline & & & \\
\hline
\end{tabular}

\section{F. Pemakalah Seminar Ilmiah (Oral Presentation) dalam 5 Tahun Terakhir}

\begin{tabular}{|c|c|c|c|}
\hline No. & $\begin{array}{c}\text { Nama Pertemuan } \\
\text { Ilmiah/Seminar }\end{array}$ & $\begin{array}{c}\text { Judul Artikel } \\
\text { Ilmiah }\end{array}$ & Waktu dan Tempat \\
\hline
\end{tabular}




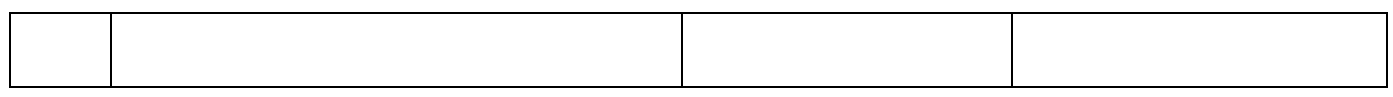

Semua data yang saya isikan dan tercantum dalam biodata ini adalah benar dan dapat dipertanggungjawabkan secara hukum. Apabila di kemudian hari ternyata dijumpai ketidak-sesuaian dengan kenyataan, saya sanggup menerima sanksi.

Demikian biodata ini saya buat dengan sebenarnya untuk memenuhi salah satu persyaratan dalam pengajuan Hibah Penelitian Dosen Pemula.

Denpasar, 29 April 2016

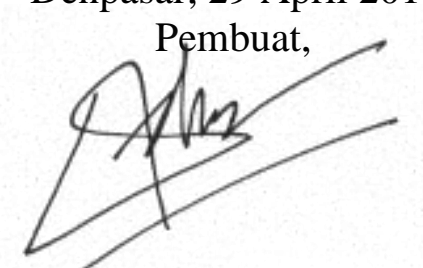

(I Nyoman Saputra Wahyu Wijaya, S.Kom., M.Cs) 


\section{SURAT PERNYATAAN KETUA PENGUSUL}

Yang bertanda tangan dibawah ini:

Nama

: Ida Bagus Ary Indra Iswara, M.Kom.

NIDN

: 0824048801

Pangkat / Golongan : Penata Muda / IIIB

Jabatan Fungsional : Asisten Ahli

Dengan ini menyatakan bahwa proposal penelitian saya yang dengan judul : Rancang Bangun Papan Ketik Android Aksara Bali dengan Perbaikan Pasang Aksara Otomatis, yang diusulkan dalam Hibah Penelitian Dosen Pemula untuk tahun anggaran 2017 bersifat original dan belum pernah dibiayai oleh lembaga / sumber dana lain.

Bilamana di kemudian hari ditemukan ketidaksesuaian dengan pernyataan ini, maka saya bersedia dituntut dan diproses sesuai dengan ketentuan yang berlaku dan mengembalikan seluruh biaya penelitian yang sudah diterima ke kas negara.

Demikian pernyatan ini dibuat dengan sesungguhnya dan dengan sebenarbenarnya.

Mengetahui, Kepala LPPM STMIK STIKOM Indonesia

Ida Bagus Ary Indra Iswara, M.Kom.

NIP/NIK: 1403210
Denpasar, 29 Mei 2016

Yang menyatakan,

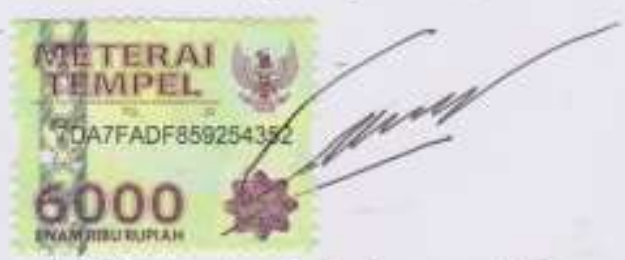

Ida Bagus Ary Indra Iswara, M.Kom.

NIP/NIK: 1403210 